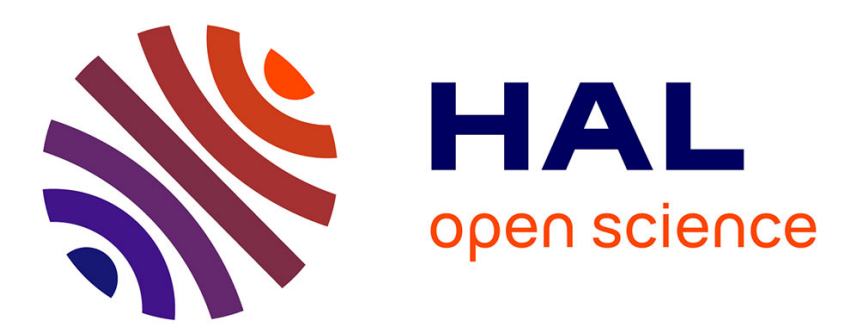

\title{
Morphological diversity and function of the stigma in Ficus species (Moraceae)
}

Simone Pádua Teixeira, Marina F.B. Costa, João Paulo Basso-Alves, Finn Kjellberg, Rodrigo A.S. Pereira

\section{To cite this version:}

Simone Pádua Teixeira, Marina F.B. Costa, João Paulo Basso-Alves, Finn Kjellberg, Rodrigo A.S. Pereira. Morphological diversity and function of the stigma in Ficus species (Moraceae). Acta Oecologica, 2018, 90, pp.117-131. 10.1016/j.actao.2018.02.008 . hal-02333104

\section{HAL Id: hal-02333104 https://hal.science/hal-02333104}

Submitted on 25 Oct 2019

HAL is a multi-disciplinary open access archive for the deposit and dissemination of scientific research documents, whether they are published or not. The documents may come from teaching and research institutions in France or abroad, or from public or private research centers.
L'archive ouverte pluridisciplinaire $\mathbf{H A L}$, est destinée au dépôt et à la diffusion de documents scientifiques de niveau recherche, publiés ou non, émanant des établissements d'enseignement et de recherche français ou étrangers, des laboratoires publics ou privés. 
Morphological diversity and function of the stigma in Ficus species (Moraceae)

Simone Pádua Teixeira ${ }^{\mathrm{a}, *}$, Marina F.B. Costa ${ }^{\mathrm{a}, \mathrm{b}}$, João Paulo Basso-Alves ${ }^{\mathrm{b}, \mathrm{c}}$, Finn Kjellberg ${ }^{\mathrm{d}}$, Rodrigo A.S. Pereira ${ }^{\mathrm{e}}$

${ }^{a}$ Faculdade de Ciências Farmacêuticas de Ribeirão Preto, Universidade de São Paulo, Av. do Café, s/n, 14040-903, Ribeirão Preto, SP, Brazil ${ }^{\text {b }}$ PPG em Biologia Vegetal, Instituto de Biologia, Universidade Estadual de Campinas, Av. Bandeirantes, 3900, 14040-901, Campinas, SP, Brazil c Instituto de Pesquisa do Jardim Botânico do Rio de Janeiro, DIPEQ, Rua Pacheco Leão, 915, 22460-030, Rio de Janeiro, RJ, Brazil d CEFE UMR 5175, CNRS, Université de Montpellier, Université Paul-Valéry Montpellier, EPHE, 1919 route de Mende, F-34293, Montpellier Cédex 5, France ${ }^{\mathrm{e}}$ Faculdade de Filosofia, Ciências e Letras de Ribeirão Preto, Universidade de São Paulo, Av. Bandeirantes, 3900, 14040-903, Ribeirão Preto, SP, Brazil 
Keywords: Brood-site pollination, Coevolution, Extra-gynoecial compitum, Synstigma, Moraceae, Nursery pollination

\begin{abstract}
The stigma plays several roles such as pollen hydration and selection, and pollen tube nutrition. In the Ficus-fig wasp mutualism, stigmata have an additional, almost unknown, function by representing a physical interface for both plant and wasp reproduction. We used light and electron microscopy to compare the detailed morphology of the stigmata of nine Ficus species of different sections and with different pollination modes and sexual expressions. Figs were collected at the stage when the stigmata were receptive for pollination. Stigmata in actively pollinated monoecious species have well developed papillae concentrated on the adaxial surface exposed towards the fig cavity. Conversely, the passively pollinated monoecious species have the whole surface of the stigmata covered by somewhat smaller papillae. In both actively and passively pollinated monoecious species these features are consistent, irrespective of style length. In all actively pollinated gynodioecious species, the stigmata of pistillate flowers were tubular or infundibuliform whereas in almost all actively pollinated monoecious species (except F. racemosa) the stigmata were filiform, with one branch or two asymmetric branches. In gynodioecious species the short-styled flowers in "male" figs show a limited receptive surface with small papillae, while the stigmata of long-styled flowers in "female" figs are covered by papillae that extend down the sides of the style, increasing the stigmatic surface. In actively pollinated species, stigmata are cohesive, forming a common surface for pollen tube germination (= synstigma). The synstigma arrangement was quite variable: lax, cohesive or very cohesive, with entanglement by stigmatic papillae and stylar trichomes. Entanglement by stylar trichomes is common in gynodioecious species. The synstigma arrangement did not correlate with phylogeny or breeding system. This study is the first to report a very loose synstigma in actively pollinated monoecious Ficus species. Our analyses revealed that, in Ficus, the synstigma is functionally analogous to an extra-gynoecial compitum. Comparative studies will be required to test further hypotheses about the evolutionary determinants of such variation.
\end{abstract}

\title{
Introduction
}

The stigma is generally the apical extension of the carpel that receives the pollen grain and intercedes in the germination of the pollen tube (Heslop-Harrison and Heslop-Harrison, 1985; Heslop-Harrison, 1992). Thus, the stigma is the site where pollination ends and the journey of the pollen tube toward the ovule begins (van Went and Willemse, 1984). Although the function of the stigma is the same for all angiosperms, stigma structure (shape, cellular composition and secretion occurrence) and physiology are very diverse (Edlund et al., 2004; Endress, 1994; Heslop-Harrison, 1992). The shape of the stigma, for example, may be of taxonomic value (Bigazzi and Selvi, 2000; Brown and Gilmartin, 1989; Heslop-Harrison, 1981), in addition to being related to adaptations to pollen grain deposition, such as the plumose stigma in the anemophilous species of Poaceae (Heslop-Harrison, 1992), or requiring the visit/manipulation 
of an animal to become receptive to pollen germination (Basso-Alves et al., 2011; Sigrist and Sazima, 2004).

As a reflection of its morphological variation, the stigma can play several roles (Edlund et al., 2004), such as hydration of pollen grains

(Edlund et al., 2004; Heslop-Harrison and Heslop-Harrison, 1985) and nutrition of growing pollen tubes (Rejón et al., 2014). Because of its ability to stimulate or prevent the emission of pollen tubes, the stigma also plays a selective role in the germination of pollen grains (HeslopHarrison, 2000; Rejón et al., 2014). This control over the access of pollen tubes to style and ovary and, consequently, to ovules, is evidenced by systems of pollen-stigma recognition and compatibility (Heslop-Harrison, 1982; Heslop-Harrison et al., 1975). It should be noted that the selective role in pollen tube growth is not restricted to the stigma (Erbar, 2003; Lora et al., 2016) but is also performed by the compitum (Endress, 1982; Wang et al., 2012). The compitum (from the Latin crossing or crossroads) is a term applied to places of convergence of several growing pollen tubes, forming a competition arena. It is found at the intersection of a pistil transmitting tissue in flowers with a syncarpic gynoecium (Carr and Carr, 1961; Endress, 2011; Erbar, 2003).

Therefore, it seems evident that stigma shape and organization are highly associated with the type of pollination (Edlund et al., 2004). However, much greater effort has been expended on elucidating the relationship between pollen and pollination (e.g., Banks and Rudall, 2016; Hesse, 2000; Osborn et al., 1991) than between stigma and pollination (Heslop-Harrison, 1992). The study of the diversity of stigmata related to various types of pollination (Basso-Alves et al., 2011; Jousselin and Kjellberg, 2001) and breeding systems (Katinas et al., 2016; Lora et al., 2011 ) is thus of great interest in general and for obligate mutualisms such as between fig trees (Ficus) and their agaonid pollinating wasps in particular (Galil and Eisikowitch, 1968).

Fig trees (Ficus L.) belong to the largest genus of Moraceae, comprising 841 of 1217 described species in the family (The Plant List, 2013). Its representatives are widely distributed in tropical, subtropical and temperate regions (Berg, 2005). The genus has as synapormorphy a distinct type of inflorescence called a syconium or fig, that consists of an urn-shaped receptacle. Internally the fig is covered by diclinous flowers (= unisexual) (Berg, 1990; Verkerke, 1989) and presents a single opening to the outside, called an ostiole (Berg, 1990; Galil and Eisikowitch, 1968). These plants are involved in a notable specialized pollination mutualism with agaonid wasps (Galil and Eisikowitch, 1968).

About half the Ficus species are monoecious. Their figs contain staminate and pistillate flowers and therefore they produce pollen and seeds and provide a breeding place for the pollinating wasps. The other Ficus species are structurally gynodioecious but functionally dioecious, i.e., some individuals carry figs with long-styled pistillate flowers which produce only seeds ("female individuals"), while others ("male individuals") have figs with staminate flowers and short-styled flowers that are used by the pollinating wasps to deposit their eggs and which produce practically no seeds. Therefore figs in "male" fig trees produce pollen and wasp offspring (Kjellberg et al., 2005). Monoecy is probably the ancestral character-state in the 
genus, with one (or more) change to gynodioecy and two reversals to monoecy (Datwyler and Weiblen, 2004; Jousselin et al., 2003b; Weiblen, 2000).

The Ficus-fig wasp mutualism probably exerts a strong selective pressure over stigma morphology, as the stigma constitutes a physical interface for both plant and wasp reproduction. Indeed, stigma morphology is correlated with the pollination mode of different fig tree species, i.e. active or passive pollination (Jousselin et al., 2003a; Jousselin and Kjellberg, 2001). About $3 / 4$ of all Ficus species are actively-pollinated. In these species females of pollinating wasps actively collect pollen from anthers before leaving their natal figs and place it in special thoracic structures called pollen pockets, in order to transport it to another fig whose pistillate flowers are receptive to pollination. Once inside a receptive fig, the female wasp removes some pollen from its pollen pockets each time it lays an egg and deposits it on the stigma surface (Galil and Eisikowitch, 1969; Ramírez -Benavides, 1969). In actively pollinated Ficus species, stigmata can be cohesive, forming a common surface for pollen tube germination (= synstigma). Since actively pollinating wasps are selected to pollinate the flower in which they have just laid an egg, the synstigma seems to play a functional role ensuring seed production by allowing lateral growth of the pollen tube and hence limiting the capacity of wasp to control which flower is fertilized (Jousselin and Kjellberg, 2001). However, in passively pollinated species stigmata are separated and elongated, brushing the surface of the wasp and thus the synstigma is absent.

The objective of the present study was to check at a detailed morphological level the stigmatic features selected in response to the Ficusfig wasp mutualism. To achieve this objective nine species of Ficus from different sections and with different modes of pollination and sexual expressions were compared in terms of stigma morphology. In addition, the morphology of stigmatic papillae in the highly cohesive synstigma of F. religiosa and F. racemosa was evaluated at the ultrastructural level. 2. Materials and methods

Nine species from eight Ficus lineages (sections) - F. auriculata (section Sycomorus), F. crocata (section Americanae), F. lyrata (section

Galoglychia), F. microcarpa (section Conosycea), F. obtusiuscula (section

Pharmacosycea), F. racemosa (section Sycomorus), F. religiosa (section Urostigma), F. septica (section Sycocarpus) and F. ulmifolia (section Sycidium) (Table 1) - were studied. Ficus auriculata and F. racemosa were included as they represent a gynodioecious and a monoecious species, respectively, in sect. Sycomorus. Species names were based on C.C. Berg (Berg and Villavicencio, 2004; Berg and Corner, 2005).

For monoecious Ficus species, stigmata of both shorter- and longerstyled pistillate flowers were analyzed. For gynodioecious species we studied long-styled flowers from figs of "female trees", except F. septica for which we studied short-styled flowers from "male trees" and longstyled flowers from "female trees".

Five figs (= inflorescences) of each species studied (from one individual/species) were collected at the stage when stigmata are receptive for pollination. Figs were cut in half and fixed in FAA 50 (formalin:acetic acid:alcohol) (Johansen, 1940) or in buffered formalin (Lillie, 1954) 
for 24-48 h, dehydrated in an ethanol series and processed for observation by light microscopy (LM), scanning electron microscopy (SEM) and transmission electron microscopy (TEM).

The external morphology of the stigmata was assessed by SEM. Previously fixed samples were dehydrated in an ethanol series, critical point dried in a Bal Tec CPD 030 critical point dryer, placed on stubs over carbon adhesive tape, and sputter coated with gold with a Bal Tec SCD 050 instrument. Images were obtained using a Jeol JSM-6610LV SEM.

Stigma anatomy was studied in samples embedded in methacrylatebased resin (Gerrits and Horobin, 1991) and cut into $5 \mu \mathrm{m}$ thick sections with a Leica RM 2245 rotary microtome. Sections were stained with $0.05 \%$ toluidine blue in phosphate buffer as a general stain (O'Brien et al., 1964) and with Sudan black B (Pearse, 1980) to detect lipophilic substances. Anatomical sections were observed and photographed using a Leica DM 5000 B light microscope coupled to a Leica DFC 320 digital camera. Crystals were observed and shot with a Leica DM5000 B light microscope provided with a polarizing filter (PLM, Johansen, 1940).

The ultrastructure of stigmatic cells was analyzed under TEM in Ficus religiosa and F. racemosa. Samples were fixed in Karnovsky's fixative (McDowell and Trump, 1976) for 24 h, post-fixed in $1 \%$ osmium tetroxide in $0.1 \mathrm{M}$ phosphate buffer $(\mathrm{pH} 7.2)$ and embedded in araldite. Ultrathin sections (60 $\mathrm{nm}$ thick) were obtained using a Leica Reichert Ultracut $\mathrm{S}$ ultramicrotome, collected on copper grids covered with Formvar, contrasted with $2 \%$ uranyl acetate and lead citrate for 15 min each (Reynolds, 1963), and examined with a Jeol 100CXII TEM.

Synstigmata were classified into cohesive or lax according to the degree of difficulty in separating fixed samples using a needle. 
For simplicity, in gynodioecious species, the fig tree containing figs with long-styled pistillate

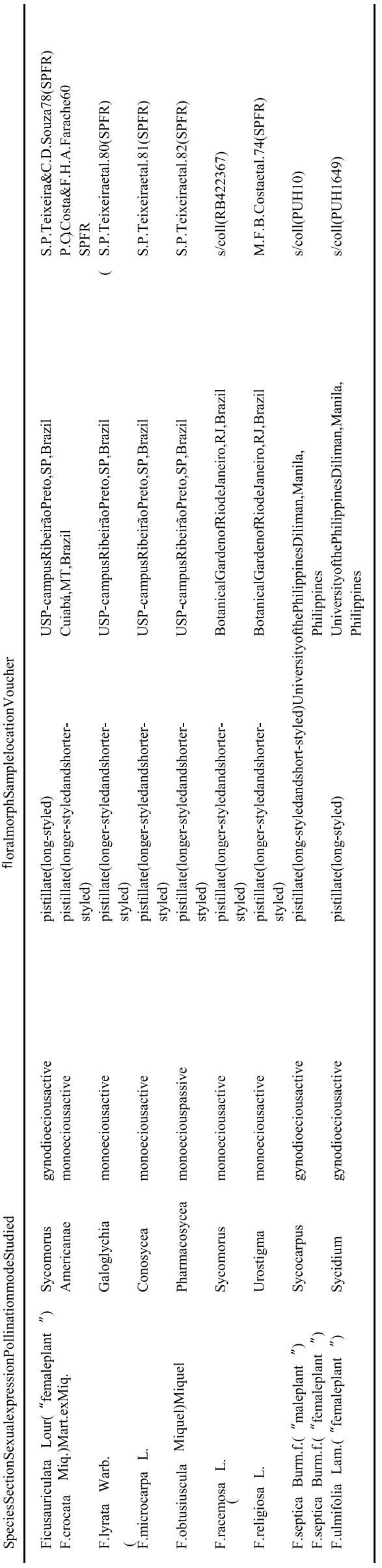


flowers which produce only seeds we called a "female plant". The one in which figs have staminate flowers producing pollen and short-styled flowers that produce wasp offspring and no or almost no seeds we called a "male plant".

\section{Results}

The stigmata of the studied Ficus species are dry but differ in shape, size, and cellular composition of the stigmatic surface (Table 2). In all actively pollinated gynodioecious Ficus species studied the stigmata of pistillate flowers were tubular or infundibuliform (Table 2). Stigmata in actively pollinated monoecious Ficus species (except F. racemosa) have the well developed papillae concentrated only on the adaxial surface exposed towards the fig cavity. Conversely, the passively pollinated monoecious species have the whole surface of the stigmata covered by somewhat smaller papillae. The short-styled flowers of "male plants" show a limited receptive surface with small papillae, while the stigmata of long-styled flowers of gynodioecious species are covered by papillae that extend down the sides, increasing the stigmatic surface.

\subsection{Ficus auriculata (gynodioecious, active)}

The stigma (pistillate flower, female inflorescences) is tubular (Fig. 1A). The contact between the stigmata is lax. A synstigma can be formed by two to several stigmata (Fig. 1B). The external stigmatic surface is formed by papillae containing phenolic compounds and numerous large, central vacuoles (Fig. 1C). No druses (groups of crystals united by their centre and of calcium oxalate, silicates, or carbonate composition) are found.

\subsection{Ficus crocata (monoecious, active)}

The stigma of the shorter- and longer-styled flowers shows two highly asymmetric filiform branches (Fig. 2A) or a filiform branch (Fig. 2B). The contact between the stigmatic branches is tight, forming a cohesive synstigma (Fig. 2C) by the adherence of uni- or bicellular trichomes that compose the whole stigmatic surface (Fig. 2D and E) and the interweaving of branches. The synstigma can be formed of two to ten stigmata. The trichomes are covered by a thin, smooth cuticle and are formed by vacuolated cells (Fig. 2E). The transmitting tissue contains druses (Fig. 2F). No phenolic cells are found.

\subsection{Ficus lyrata (monoecious, active)}

The stigma of the shorter- and longer-styled flowers shows a filiform branch (Fig. 3A), and sometimes a second very shortened branch is apparent (Fig. 3B). The contact between the stigmatic branches is tight, forming a cohesive synstigma (Fig. 3C and D) by the adherence of uni-, bi- or tricellular trichomes that compose the adaxial stigmatic surface (Fig. 3D-F). The trichomes are covered by a thin, smooth cuticle and are formed by vacuolated cells (Fig. 3F). 
Phenolic content is frequently observed in the basal cells of trichomes (Fig. 3F). The transmitting tissue contains druses (Fig. 3G).

\subsection{Ficus microcarpa (monoecious, active)}

The stigma of the shorter- and longer-styled has a filiform branch (Fig. 4A, E), and more rarely a second, very shortened branch (Fig. 4B). The contact between the stigmatic branches is lax, forming an atypical synstigma usually involving only two stigmata (Fig. 4C and D). The adaxial stigmatic surface is formed by papillae (Fig. 4D-F) covered with a thin, smooth cuticle (Fig. 4F). The transmitting tissue has some cells that contain druses (Fig. 4G). No phenolics are found.

\subsection{Ficus obtusiuscula (monoecious, passive)}

The stigma of the shorter- and longer-styled flowers displays two filiform branches, often unequal in length: shorter and less exposed in

Table 2

Stigma morphology of the Ficus species studied. SSF = shorter-styled flower, LSF = longerstyled flower, NA = not applicable, $+=$ present, $-=$ absent .

\begin{tabular}{|c|c|c|c|c|c|c|c|}
\hline Species & $\begin{array}{l}\text { Floral } \\
\text { morph }\end{array}$ & Shape & $\begin{array}{l}\text { Synstigma } \\
\text { arrangement }\end{array}$ & $\begin{array}{l}\text { Cuticle } \\
\text { thickness and } \\
\text { ornamentation }\end{array}$ & $\begin{array}{l}\text { Surface } \\
\text { cellular } \\
\text { composition }\end{array}$ & $\begin{array}{l}\text { Druse } \\
\text { occurrence }\end{array}$ & $\begin{array}{l}\text { Phenolic } \\
\text { cell } \\
\text { occurrence }\end{array}$ \\
\hline $\begin{array}{c}\text { Ficus } \\
\text { auriculata }\end{array}$ & LSF & tubular & $\begin{array}{l}\text { lax, } 1 \text { to } \\
\text { several } \\
\text { stigmata }\end{array}$ & thin, smooth & papillae & - & + \\
\hline F. crocata & $\begin{array}{l}\text { SSF } \\
\text { LSF }\end{array}$ & $\begin{array}{l}2 \text { highly } \\
\text { asymetric } \\
\text { filiform } \\
\text { branches }\end{array}$ & $\begin{array}{l}\text { cohesive, } 2 \\
\text { to } 10 \\
\text { stigmata }\end{array}$ & thin, smooth & $\begin{array}{l}\text { uni or } \\
\text { bicelular } \\
\text { trichome }\end{array}$ & + & - \\
\hline F. lyrata & $\begin{array}{l}\text { SSF } \\
\text { LSF }\end{array}$ & $\begin{array}{l}1 \text { filiform } \\
\text { branch; rarely a } \\
\text { second short } \\
\text { branch }\end{array}$ & $\begin{array}{l}\text { cohesive, } 2 \\
\text { to several } \\
\text { stigmata }\end{array}$ & thin, smooth & $\begin{array}{l}\text { uni to } \\
\text { tricellular } \\
\text { trichome }\end{array}$ & + & + \\
\hline $\begin{array}{l}\text { F. } \\
\text { microcarpa }\end{array}$ & $\begin{array}{l}\text { SSF } \\
\text { LSF }\end{array}$ & $\begin{array}{l}1 \text { filiform } \\
\text { branch; rarely a } \\
\text { shortened } \\
\text { branch }\end{array}$ & $\begin{array}{l}\text { lax, } \\
\text { generally } 2 \\
\text { stigmata }\end{array}$ & thin, smooth & papillae & + & - \\
\hline $\begin{array}{l}\text { F. } \\
\text { obtusiuscula }\end{array}$ & $\begin{array}{l}\text { SSF } \\
\text { LSF }\end{array}$ & $\begin{array}{l}2 \text { short filiform } \\
\text { branches } \\
2 \text { long } \\
\text { asymmetric }\end{array}$ & NA & $\begin{array}{l}\text { thin, } \\
\text { ornamented }\end{array}$ & $\begin{array}{l}\text { short } \\
\text { papillae } \\
\text { papillae }\end{array}$ & + & + \\
\hline
\end{tabular}




\begin{tabular}{|c|c|c|c|c|c|c|c|}
\hline & & $\begin{array}{l}\text { filiform } \\
\text { branches }\end{array}$ & & & & & \\
\hline F. racemosa & $\begin{array}{l}\text { SSF } \\
\text { LSF }\end{array}$ & infundibuliform & $\begin{array}{l}\text { very } \\
\text { cohesive, } \\
\text { several } \\
\text { stigmata }\end{array}$ & $\begin{array}{l}\text { thin, } \\
\text { ornamented }\end{array}$ & papillae & + & - \\
\hline F. religiosa & $\begin{array}{l}\text { SSF } \\
\text { LSF }\end{array}$ & $\begin{array}{l}1 \text { filiform } \\
\text { branch }\end{array}$ & $\begin{array}{l}\text { very } \\
\text { cohesive, } \\
\text { several } \\
\text { stigmata }\end{array}$ & thin, smooth & $\begin{array}{l}\text { long } \\
\text { papillae }\end{array}$ & + & + \\
\hline F. septica & $\begin{array}{l}\text { SSF } \\
\text { LSF }\end{array}$ & infundibuliform & $\begin{array}{l}\text { NA } \\
\text { cohesive; } 1\end{array}$ & thin, smooth & $\begin{array}{l}\text { convex cell } \\
\text { papillae }\end{array}$ & - & + \\
\hline F. ulmifolia & LSF & tubular & $\begin{array}{l}\text { to several } \\
\text { stigmata } \\
\text { lax; } 1 \text { to } \\
\text { several } \\
\text { stigmata }\end{array}$ & thin, smooth & papillae & - & - \\
\hline
\end{tabular}

shorter-styled flowers (Fig. 5A and B), and long, facing the fig cavity in longer-styled flowers (Fig. 5C and D). There is no contact between the stigmatic branches and therefore there is no synstigma (Fig. 5E). The stigmatic surface is formed by strongly vacuolated papillae (Fig. 5B, D) covered by a thin, ornamented cuticle. Papillae can have phenolic content (Fig. 5B, D). The length of the stigmatic branches and the papilla distribution are the main differences between the longer- and shorter-styled flowers (Fig. 5). The elongated stigmatic branches of longerstyled flowers reach much longer into the fig cavity than the short stigmatic branches of shorterstyled flowers. Papillae extend down the sides on the stigma of longer-styled flowers (Fig. 5A and B), whereas they are concentrated on the adaxial surface in shorter-styled flowers (Fig. 5C and D). The transmitting tissue has cells that contain druses (Fig. 5F).

\subsection{Ficus racemosa (monoecious, active)}

The stigma of the shorter- and longer-styled flowers is infundibuliform (Fig. 6A-C). The contact between the stigmata is tight, forming a cohesive and continuous synstigma (Fig. 6A) through the entanglement of papillae (Fig. 6B-D). The papillae are covered by a thin, ornamented cuticle. The cohesion between the stigmatic papillae is done by cell walls (Fig. 6E$\mathrm{G})$, a fact that makes the manual separation of stigmata difficult. In the region of contact between the papillae of different stigmata the middle lamella is discontinuous (Fig. 6F) or even missing (Fig. 6G), indicating that there is union between two cell walls. The transmitting tissue is composed of elongated or isodiametric cells that are vacuolated, have a dense cytoplasm, a conspicuous nucleus and sometimes druses. 


\subsection{Ficus religiosa (monoecious, active)}

The stigma of the shorter- and longer-styled flowers has two highly asymmetric filiform branches. There is tight contact between the stigmatic branches, forming a cohesive and continuous synstigma (Fig. 7A) through the entanglement of long papillae that compose the stigmatic surface (Fig. 7B). The papillae are covered by a thin, smooth cuticle (Fig. 7C) and may contain phenolic compounds (Fig. 7B). The transmitting tissue consists of isodiametric cells that can contain druses (Fig. 7D). The cohesion between the stigmatic papillae is done by cell walls (Fig. 7E, F), a fact that makes the manual separation of stigmata difficult. In the region of contact between the papillae of different stigmata the middle lamella is discontinuous (Fig. 7E) or even nonexistent (Fig. 7F), indicating that there is union between two cell walls.

\subsection{Ficus septica (gynodioecious, active)}

The stigma of short-styled pistillate flowers (Fig. 8A) of "male figs" and long-styled pistillate flowers (Fig. 8B) of "female figs" is infundibuliform. There is no contact between the stigmata of short-styled flowers and therefore there is no formation of a synstigma (Fig. 8C). Conversely, the stigmata of long-styled flowers can be solitary or form groups of synstigma (Fig. 8B, D). The stigmata are tightly connected to each other by stigmatic papillae and stylar unicellular trichomes (Fig. 8B). The stigmatic surface is formed by slightly convex cells in short-styled flowers (Fig. 8E). The papillae in long-styled flowers extend down the sides of the stigma (Fig. 8F), are covered by a thin, smooth cuticle (Fig. 8G) and have phenolic content. The transmitting tissue is composed of isodiametric or elongated cells that have a dense cytoplasm and a prominent nucleus (Fig. 8E and F). There are no druses.

\subsection{Ficus ulmifolia (gynodioecious, active)}

The stigma of long-styled flowers of "female figs" is tubular (Fig. 9A). The stigma may be solitary or form a synstigma with several connected stigmata (Fig. 9A-C). The receptive stigmatic surface is formed by papillae (Fig. 9A, C, D) covered by a thin, smooth cuticle (Fig. 9D). The transmitting tissue is composed of elongated or isodiametric cells with a dense cytoplasm and a conspicuous nucleus. No druses or phenolic cells are observed. 
4. Discussion
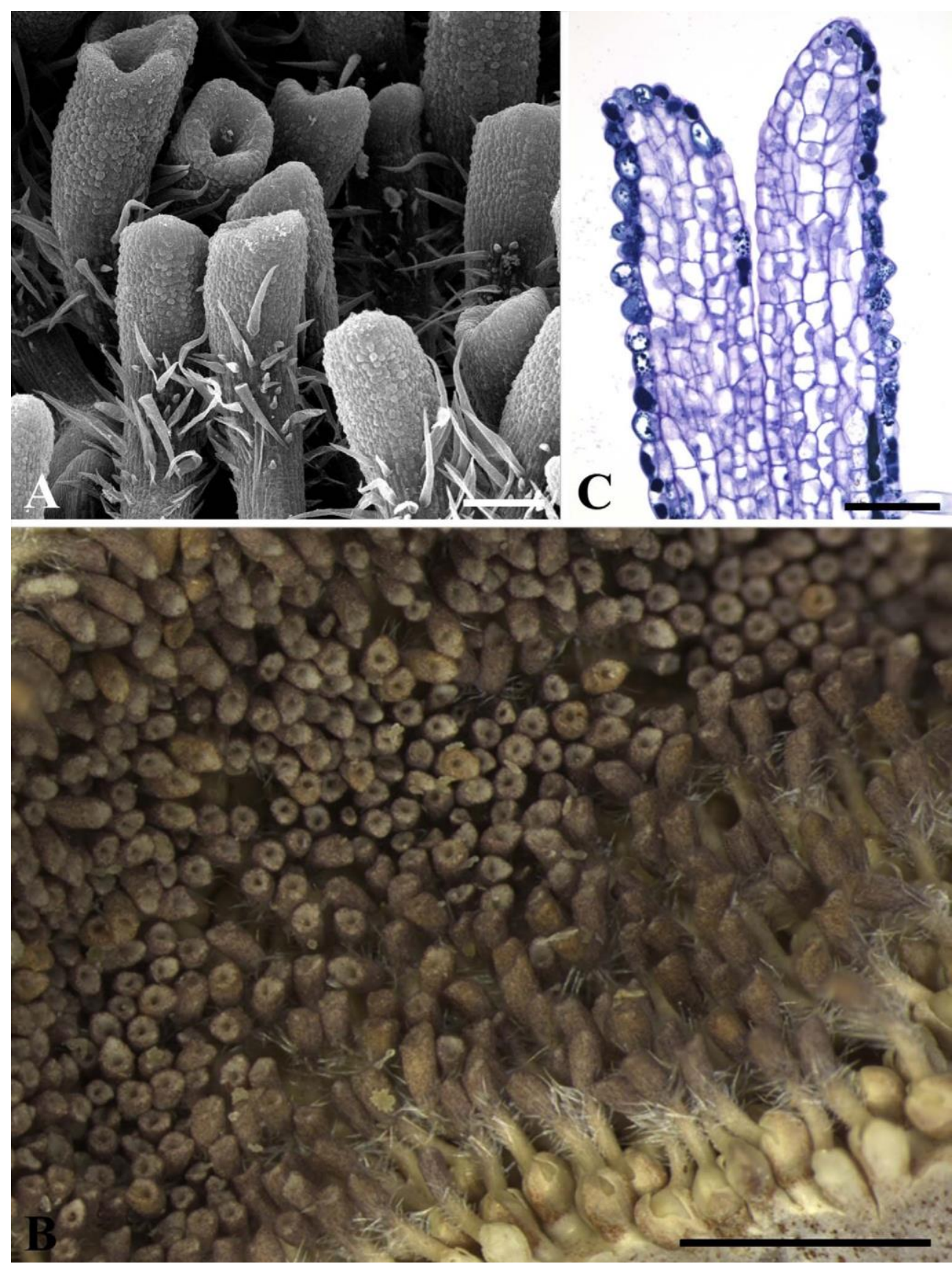
Fig. 1. Stigmata of long-styled flowers of Ficus auriculata (gynodioecious, active, "female syconium"). A. Tubular stigmata (SEM). B. Synstigma formed by the entanglement of stylar trichomes and of stigmatic papillae (LM). C. Short phenolic papillae (dark blue content) forming the stigmatic extension (LM). Scale bars: $A=100 \mu \mathrm{m} ; \mathrm{B}=1 \mathrm{~mm} ; \mathrm{C}=50 \mu \mathrm{m}$

The fundamental structure of Moraceae pistillate flowers includes a gynoecium formed by two carpels, one of which does not produce an ovule, but can provide a second stigma (Eckardt, 1937; Payer, 1857). In several genera the stigmatic branches are unequal in length and some species have a single stigmatic branch (Berg, 1989). Our morphological observations of Ficus should be interpreted within that framework. We show here wide variation in stigma structure among Ficus species. This variation can be analyzed within the context of variation in the fig species' biology and evolutionary history. Four basic types of reproductive systems are present in Ficus and could be expected to lead to convergent stigma adaptations. Ficus species may be monoecious or gynodioecious, and they may be actively or passively pollinated. In actively pollinated species, the wasps load pollen into specialized pollen pockets before leaving their natal fig, and each time they have deposited an egg into an ovule, before removing the ovipositor, they collect some pollen from the pocket and deposit it on the stigmata. In passively pollinated species, the body of the wasps becomes covered with pollen before they leave their natal fig, and when they enter a receptive fig, pollen is passively deposited, often due to the fact that the elongated stigmata brush the surface of the body of the wasp. In monoecious figs, pistillate flowers presenting a shorter pedicel and those located closer have longer styles and produce mainly seeds while pistillate flowers presenting a longer pedicel and located further from the fig wall often host insect larvae instead. Wasp larvae develop at the expense of developing endosperm (Jansen-González et al., 2012). The endosperm may be triploid, initiated through the double fertilization of the fig embryo sac, or diploid, initiated parthenogenetically by the activity of pollinator larvae (Leclerc du Sablon, 1908). Data from a number of species show that passively pollinating wasp species do not benefit from carrying pollen, and that wasp larvae, in general, probably induce the parthenogenetic development of the endosperm, while in actively pollinating species the wasp larvae mainly rely on double fertilization to induce the developement of the endosperm (Beck and Lord, 1988a; Jansen-González et al., 2012; Verkerke, 1987, 1986).

Our results show that the stigmata of the Ficus species studied show a diversity of morphological traits regarding their format, relative size of their branches and composition of the cellular surface. Despite their diversity, morphological specialization patterns were identified in pistillate flowers depending on the pollination mode. About one third of Ficus species are passively pollinated (Kjellberg et al., 2001). Reconstructions of the ancestral character state have suggested that active pollination has independently reverted to passive pollination at least five times (Jousselin et al., 2003b). 

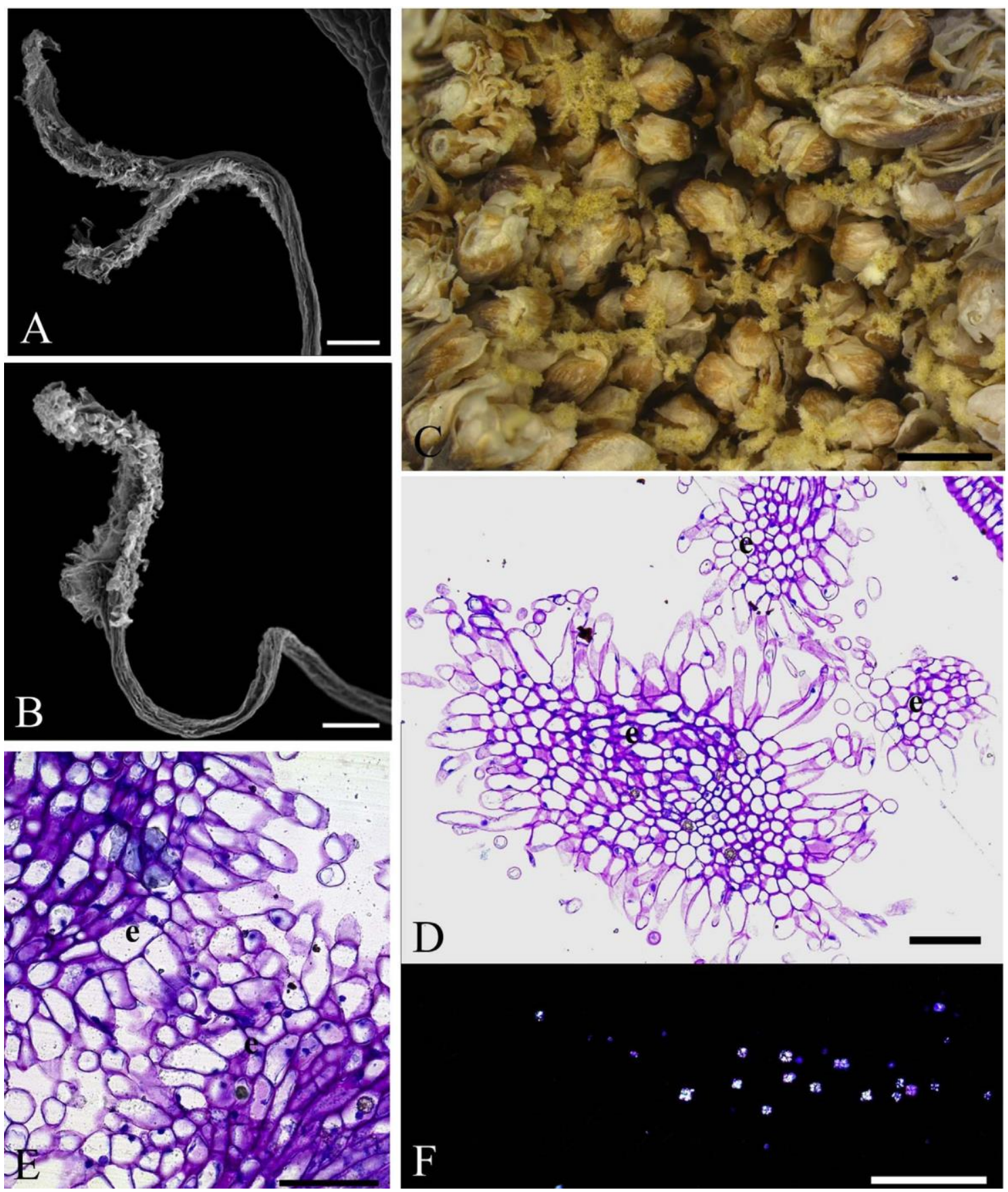

Fig. 2. Stigmata of longer-styled flowers of Ficus crocata (monoecious, active). A. Stigma with two highly asymmetric filiform branches (SEM). B. Stigma with a single filiform branch (SEM). C. Synstigma formed by the entanglement of stigmatic trichomes (LM). D. Anatomy of a synstigma formed by three stigmas (transverse section, LM). E. Detail of a synstigma showing the entangled stigmatic trichomes. Note that they are formed by one or two cells (transverse section, LM). F. Transmitting tissue with druses (longitudinal section, PLM)

Symbols: e = stigma. Scale bars: $A, B=100 \mu \mathrm{m} ; \mathrm{C}=1 \mathrm{~mm} ; \mathrm{D}, \mathrm{F}=100 \mu \mathrm{m} ; \mathrm{E}=50 \mu \mathrm{m}$. 
In the passively pollinated monoecious F. obtusiuscula, the stigmatic branches of shorterstyled flowers are short with papillae concentrated on the upper surface and not extending down the sides, whereas the longer-styled flowers have two long stigmatic branches with papillae covered by an ornamented cuticle extending further than the short stigmata into the cavity of the fig, increasing the stigmatic extension and thus the chance of being pollinated (see Fig. 10). This is in agreement with the observation of more abundant pollen deposition on longer-styled flowers than on shorter-styled flowers in F. maxima, another species of section Pharmacosycea (Jousselin et al., 2004).

According to Berg (2006), two distinct spatial presentations of the stigmata can be observed in section Pharmacosycea. In subsection Bergianane stigmata of longer-styled and shorterstyled flowers may reach the same height while in subsection Petenense stigmata of longerstyled flowers may project further into the fig cavity than those of shorterstyled flowers. Our observations on F. obtusiuscula as well as our unpublished obervations on F. adhatodifolia contradict this separation since both species belong to subsection Bergianae while the arrangement of flowers corresponds to Berg's description for subsection Petenense. We conclude that there is a single disposition of pistillate flowers in section Pharmacosycea, an arrangement in which the stigmata of longer-styled flowers project into the fig cavity and get most of the 

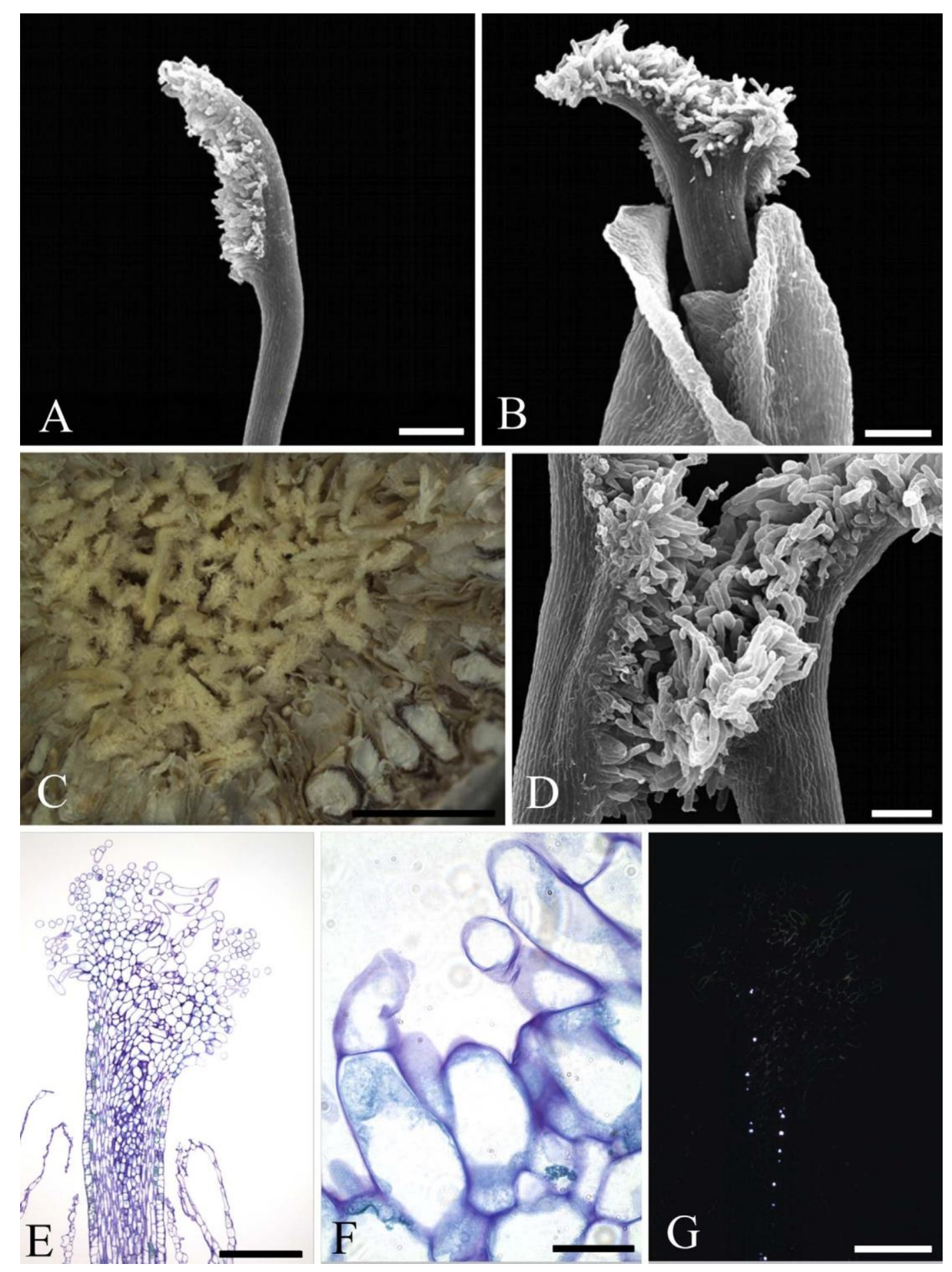

Fig. 3. Stigmata of longer-styled (A, C, D) and shorter-styled (B, E, F, G) flowers of Ficus lyrata (monoecious, active). A. Stigma with a filiform stigmatic branch (SEM). B. Stigma with two highly asymmetric filiform branches (SEM). C. Cohesive synstigma (LM). D. Synstigma of two stigmata formed by the entanglement of trichomes (SEM). E. Stigmatic trichomes formed by one, two or three cells (LM). F. Trichomes covered by a thin, smooth cuticle and with phenolic content (LM). G. Transmitting tissue with druses (PLM). Scale bars: A, B, E, G = $200 \mu \mathrm{m} ; \mathrm{C}=2 \mathrm{~mm} ; \mathrm{D}=100 \mu \mathrm{m} ; \mathrm{F}=20 \mu \mathrm{m}$ 

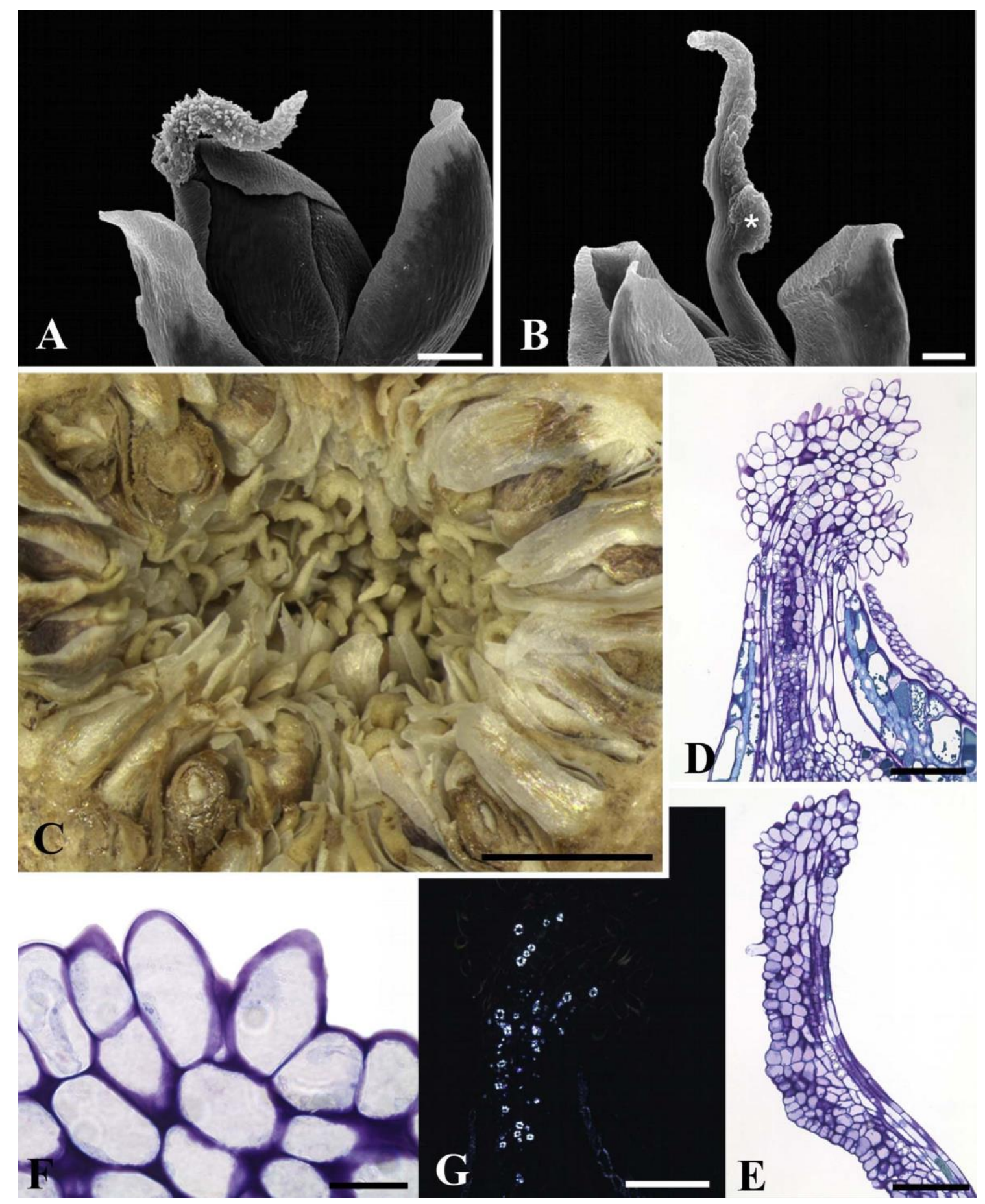
Fig. 4. Stigmata of shorter-styled (A, D, F, G) and longer-styled (B, E) pistillate flowers of Ficus microcarpa (monoecious, active). A. Stigma formed by a filiform branch (SEM). B. Stigma formed by two highly asymmetric branches (* indicates the smaller branch) (SEM). C. Lax synstigma (LM). D. Contact between two stigmata (LM). E. Filiform papillose stigma (LM). F. Papillae in detail showing the thin, smooth cuticle (LM). G. Druses in the transmitting tissue (PLM). Scale bars: $A=200 \mu \mathrm{m} ; \mathrm{B}, \mathrm{G}=100 \mu \mathrm{m} ; \mathrm{C}=1 \mathrm{~mm} ; \mathrm{D}, \mathrm{E}=100 \mu \mathrm{m} ; \mathrm{F}=20 \mu \mathrm{m}$.

pollen while those of shorter-styled flowers do not reach the fig cavity and get little pollen (Jousselin et al., 2004). The phylogenetic placement of section Pharmacosycea within the genus Ficus is still controversial since this section corresponds to a recent diversification from an old stock, but it may be quite basal within Ficus and passive pollination could be ancestral (Cruaud et al., 2012, see Fig. 10). Some observations are also available for another passively pollinated Ficus belonging to a clade that is of active pollination ancestry, namely F. curtipes (subgenus Urostigma, section Conosycea) which is pollinated by a species of Waterstoniella (Cruaud et al., 2010). An active pollination ancestry can be inferred from the presence of relictual pollen pockets in the genus Waterstoniella (Kjellberg et al., 2001). In F. curtipes, the stigmata have highly asymmetric filiform branches (giving a monofid aspect) and not two long stigmatic branches, but project into the fig cavity without forming a syntigma (Zhang et al., 2009), and the stigmata of the longer-styled flowers project further than those of shorterstyled flowers into the fig cavity (Li Z., pers. com.). The connection of pollination mode and stigma morphology is evident in section Malvanthera, subgenus Urostigma. Subsections Hesperidiiformes and Malvantherae are representatives of an ancient condition of passive pollination in Malvanthera. In these groups in general traces of pollen pockets are absent in the pollinator species and fig species have stigmata with two long stigmatic branches. In Subsection Platypodeae there is active pollination and a transition to passive pollination. Pollinators representing this recent transition to passive pollination have relictual pollen pockets and their host fig species in general have stigmata with highly asymmetric branches or polymorphic stigmata (Rønsted et al., 2008). In conclusion, monoecious species (and their pollinators) that correspond to recent transitions to passive pollination, such as F. curtipes and some species of subsection Platypodeae, probably share some morphological traits of actively pollinated species due to phylogenetic inertia. 
The arrangement of stigmata in passively pollinated gynodioecious figs was analyzed in the case of Ficus carica (Beck and Lord, 1988b). In "female plants", the pistillate flowers show stigmata with two elongated branches very similar to those of the longer-styled stigmata of $\mathrm{F}$. obtusiuscula with the presence of papillae all around the stigmatic branches. Pistillate flowers of "male plants" showed stigmata with two much shorter branches. Furthermore, the receptive

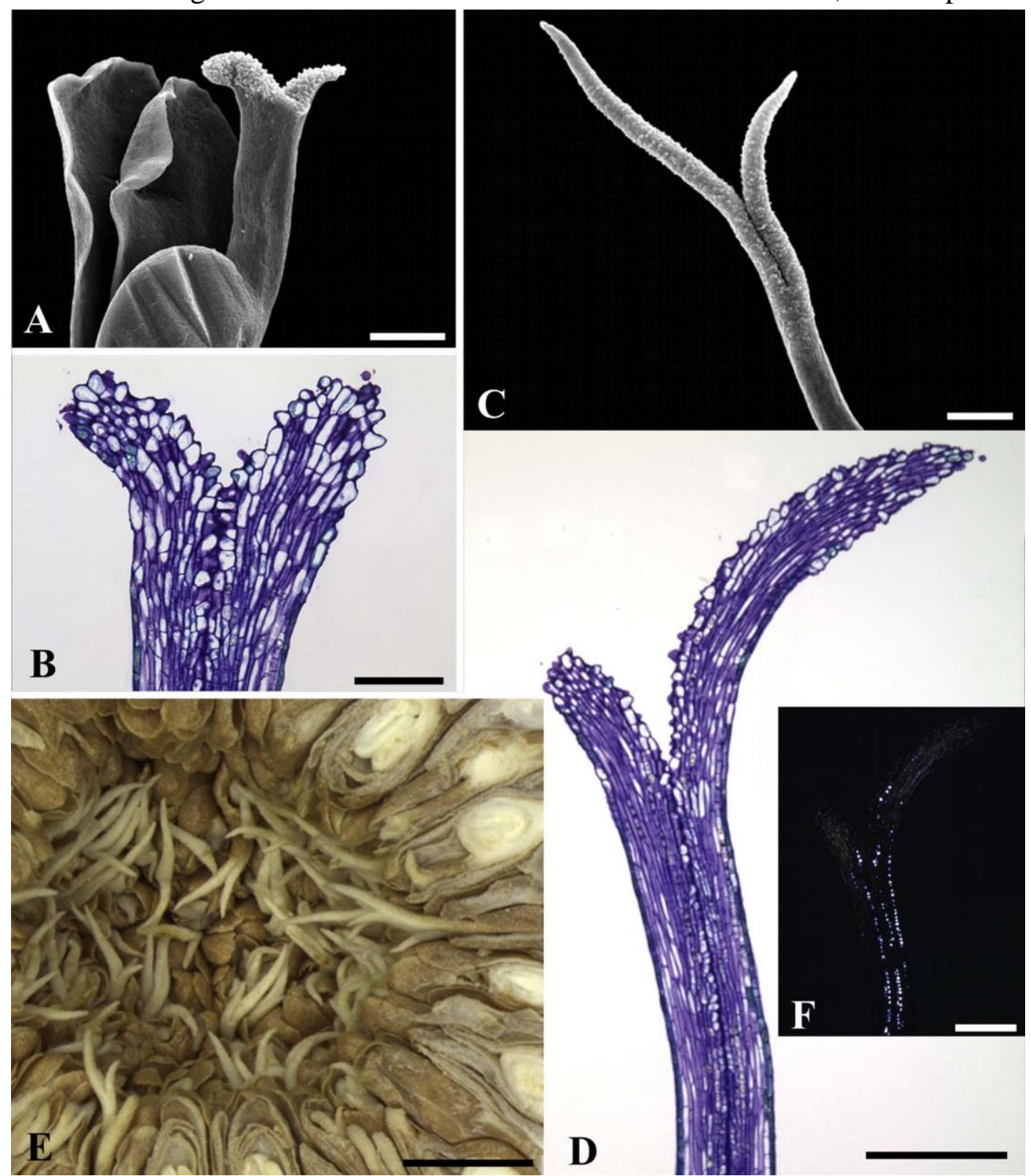

Fig. 5. Stigmata of shorter-styled (A, B) and longer-styled (C, D, E, F, G) flowers of Ficus obtusiuscula (monoecious, passive). A. Stigma formed by two short symetric filiform branches (SEM). B. Stigmatic branches covered by papillae concentrated on the adaxial side (LM). C. Stigma formed by two long asymetric filiform branches (SEM). D. Stigmatic branches covered by papillae spread on the adaxial and abaxial sides (LM). E. Stigmatic branches without contact 
(LM). Note that the stigmatic branches are shorter and less exposed in shorter-styled flowers and longer facing the syconium cavity in longer-styled flowers. F. Transmitting tissue with druses (PLM). Scale bars: A,C, D, F = $200 \mu \mathrm{m} ; \mathrm{B}=100 \mu \mathrm{m} ; \mathrm{E}=1 \mathrm{~mm}$

surface was reduced as in F. obtusiuscula. There is, however, a major difference since in "male plants" pollen germination and pollen tube growth are poor and may even be stopped by callose plugs, an adaptation that limits seed production in "male figs", while no such observation has been made in monoecious passively pollinated figs (Jousselin and Kjellberg, 2001). Indeed, for the passively pollinated gynodioecious species for which experimental data are available, the proportion of pollen germination is significantly lower on stigmata of short-styled flowers (Jousselin and Kjellberg, 2001), and in F. deltoidea, a passively pollinated gynodioecious species, embryo sac fertilization in short-styled flowers is rare because only about $20 \%$ of all deposited pollen grains germinate and, among those that germinate, more than $70 \%$ of the resulting pollen tubes are blocked by a callose plug (Jousselin and Kjellberg, 2001). Therefore, stigma shape and its cellular composition seem to play a functional role in the mutualism for these species, leading to specialization in seed or wasp production (i.e., pollen-vector) in passively pollinated species.

For monoecious actively pollinated species we analyzed Ficus crocata, F. lyrata, F. microcarpa and F. religiosa belonging to lineages that may be of exclusively monoecious ancestry and one species (F. racemosa) belonging to a lineage of gynodioecious ancestry (see Fig. 10). In the species of monoecious ancestry, the stigmata show two highly asymmetric branches, giving the aspect of a single elongated branch. They are not comparable to the stigmata of F. obtusciuscula as they do not project into the fig cavity. Instead they form an imperfect platform and only the side of the stigma turned towards the fig cavity presents numerous conspicuous elongated papillae. While we observed much variation in the precise arrangement of the stigmata, the general pattern was homogeneous. What is heterogeneous is the connectivity between stigmata. In some cases synstigmata are extremely intimate as in F. religiosa, while in other species the connection is lax. The disposition of stigmata in F. racemosa was very different and must be interpreted by comparison with the stigmata of actively pollinated gynodioecious species.

In all actively pollinated gynodioecious Ficus species, the stigmata of 

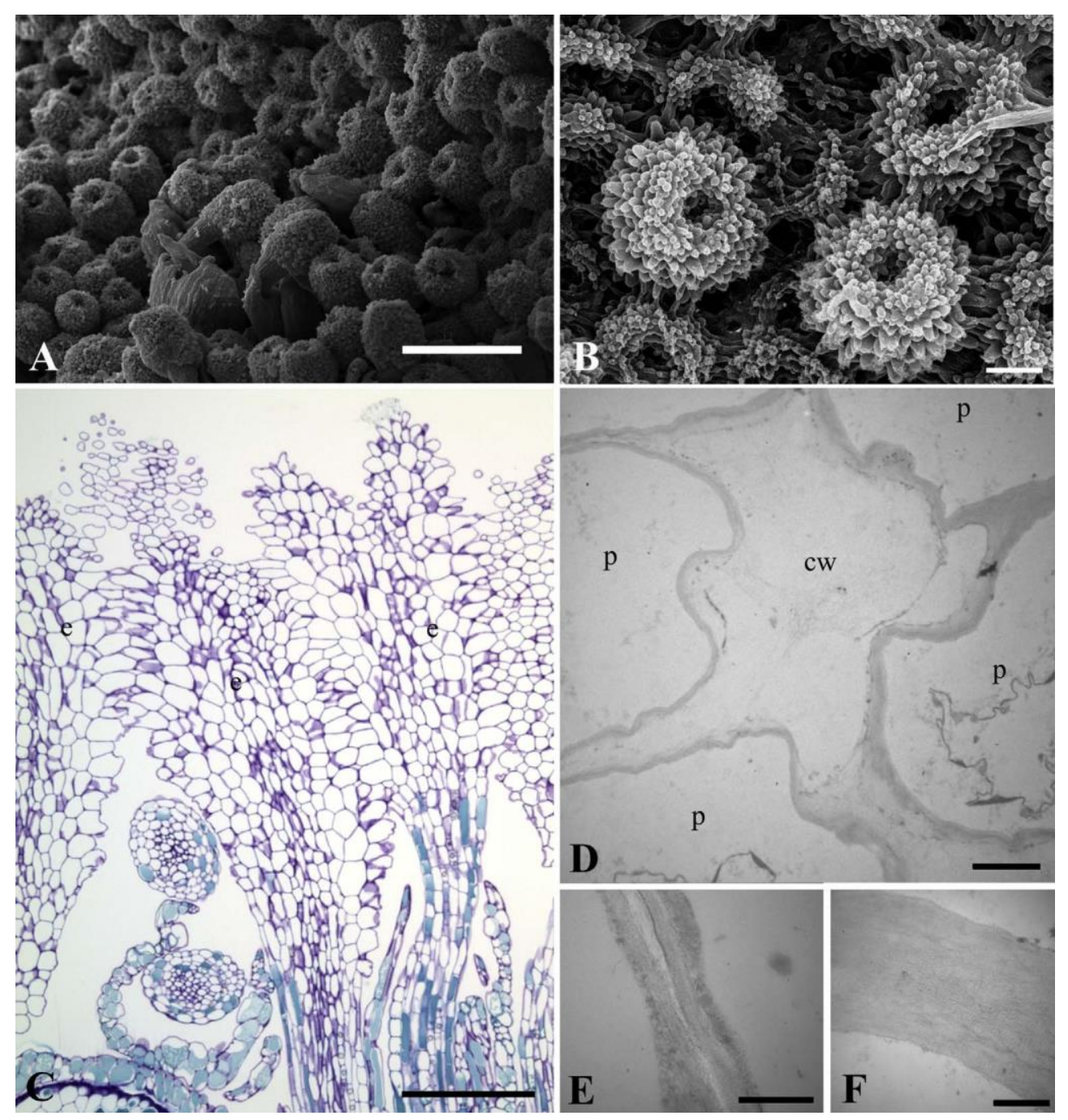

Fig. 6. Stigmata of pistillate flowers of Ficus racemosa (monoecious, active). A. Cohesive and continuous synstigma (SEM). B. Detail of the synstigma surface formed by the tight entanglement of papillae (SEM). C. Anatomy of the synstigma showing the tight entanglement of papillae (LM). D. Detail of the union of cell walls of several papillae (TEM). E. Two cell walls showing a discontinous middle lamella (TEM). F. Two cell walls showing no middle lamella (TEM). Symbols: $\mathrm{cw}=$ cell wall; $\mathrm{e}=$ stigma, $\mathrm{p}=$ papilla. Scale bars: $\mathrm{A}=500 \mu \mathrm{m}$ $\mathrm{B}=100 \mu \mathrm{m} ; \mathrm{C}=200 \mu \mathrm{m} ; \mathrm{D}=3 \mu \mathrm{m} ; \mathrm{E}, \mathrm{F}=1 \mu \mathrm{m}$.

pistillate flowers were tubular or infundibuliform (see Fig. 10). The short-styled flowers of "male plants" show a limited receptive surface with small papillae, as in F. septica of subgenus Sycomorus (this study) and F. asperifolia of subgenus Sycidium (Verkerke, 1989), while the stigmata of long-styled flowers of gynodioecious species are covered by papillae that extend 
down the sides, increasing the stigmatic surface (Verkerke, 1989; present study). In "male figs", the consistently tubular shape of stigmata, without elongated branches and with a limited receptive surface, agrees with their interpretation as an adaptation allowing female wasps to deposit pollen precisely on the stigma of the flower into which their ovipositor is inserted just after laying an egg into the ovule (Jousselin and Kjellberg, 2001). The presence of tubular stigmata in "female figs" may be due to genetic correlations between "male and female plants". In this context, a synstigma can be seen as an adaptation that can favor secondary dispersal of pollen tubes when pollen deposition is limiting. In agreement with a hypothesis of frequent limiting numbers of pollen grains, fig pollen is exceptionally small in size for insect-pollinated plants (about $10 \mu \mathrm{m}$ ), in both actively and passively pollinated Ficus species (Wang et al., 2014). This feature suggests selection for increased numbers of pollen grains due to limiting pollen, rather than selections for competitive capacity of the pollen tubes. In agreement, conditions of pollen loading in parental figs were shown to affect the pollination capacity of pollinating wasps in an actively and a passively pollinated Ficus species (Kjellberg et al., 2014). Variation in cohesiveness of stigmata into forming a synstigma could be interpreted as a result of stronger or weaker selection favoring secondary pollen dispersal by lateral growth of pollen tubes resulting from more or less clumped deposition of pollen by the wasps. An extreme situation for actively pollinated figs can be found in "female figs" of F. montana in which stigmata are perfectly separated (F. Kjellberg, unpublished data). Within Ficus, tubular or infundibuliform stigmata are perhaps found in all actively pollinated gynodioecious species and in all the species belonging to subgenus Sycomorus that have reverted to monoecy, including all species of section Sycomorus subsection Sycomorus, but also F. microdyctia and F. pritchardii (Corner, 1970). Hence, the stigmatic structure documented here in the monoecious Ficus racemosa (and in Ficus sur, Verkerke, 1989) is to be explained by the combination of active pollination and dioecious ancestry.

The synstigma arrangement of the Ficus species studied was quite variable. The entanglement of stigmata can be lax (e.g., F. auriculata, F. microcarpa and F. ulmifolia), cohesive (e.g., F. lyrata and F. septica) or very cohesive (F. racemosa and F. religiosa). This synstigma arrangement is clearly not correlated with the phylogenetic position of the species or with their breeding system (see Tables 1 and 2, Fig. 10). The entanglement of stigmata can occur by trichomes found on the style or by stigmatic papillae. Entanglement by stylar trichomes is common in 

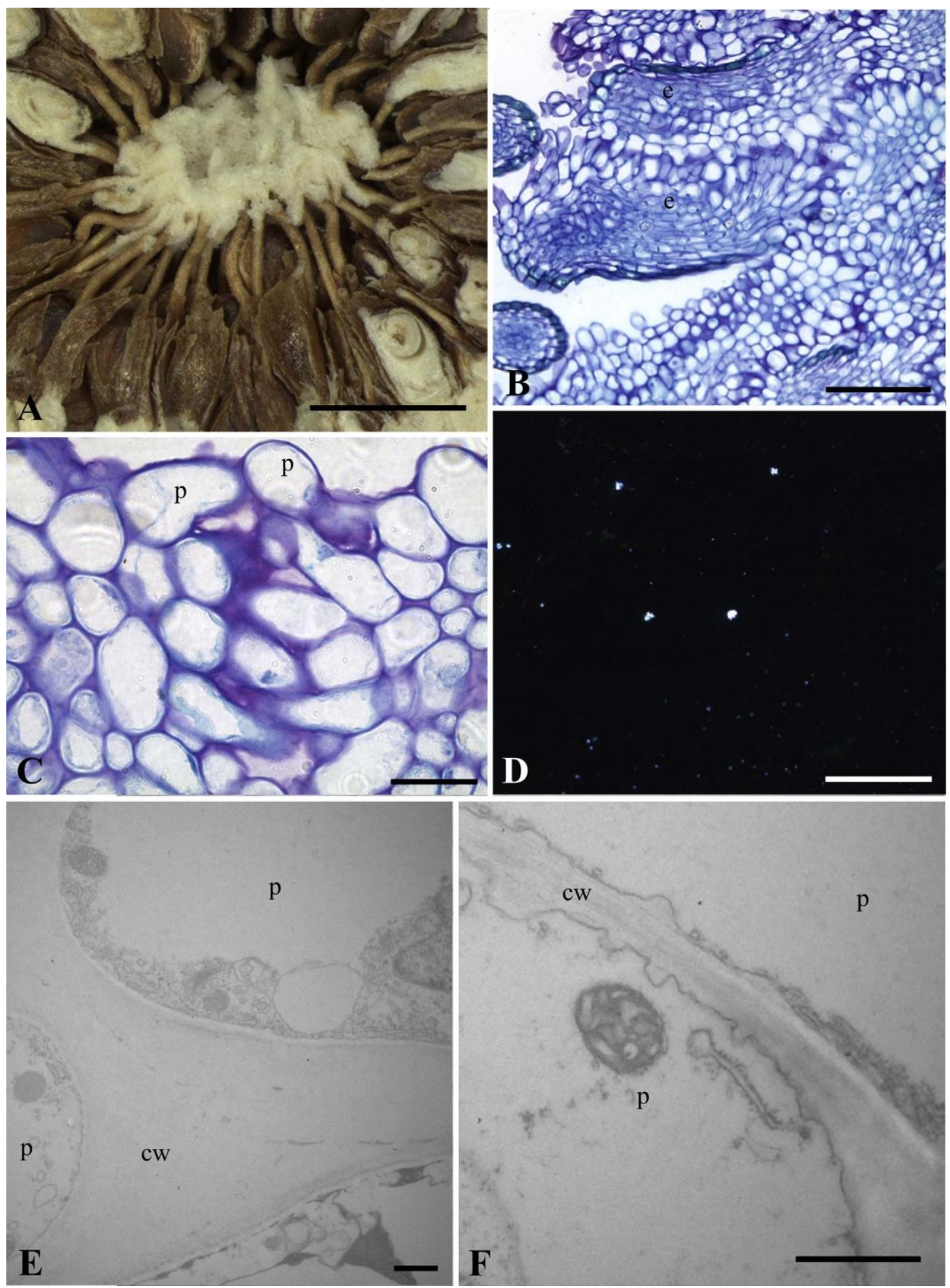

Fig. 7. Stigmata of pistillate flowers of Ficus religiosa (monoecious, active). A. Cohesive and continuous synstigma (LM). B. Synstigma formed by the entanglement of long papillae (LM). C. Detail of papillae in a connection of two stigmata (LM). D. Druses in the transmitting tissue 
cells (PLM). E. Two cell walls showing a discontinous middle lamella (TEM). F. Two cell walls showing no middle lamella $($ TEM). Symbols: $\mathrm{cw}=$ cell wall; $\mathrm{e}=$ stigma, $\mathrm{p}=$ papilla. Scale bars: $\mathrm{A}=1 \mathrm{~mm} ; \mathrm{B}, \mathrm{D}=100 \mu \mathrm{m} ; \mathrm{C}=20 \mu \mathrm{m}, \mathrm{E}, \mathrm{F}=1 \mu \mathrm{m}$

gynodioecious Ficus species, especially in the sections Sycomorus [e.g., F. auriculata (present study)], Sycocarpus [e.g., F. septica (present study), F. dammaropsis (Corner, 1978) and F. hispida (Basso-Alves et al., 2014)] and Sycidium [e.g., F. asperifolia (Verkerke, 1987)]. However, intrasection variation in the type of stigma entanglement can occur, as observed in F. racemosa comparatively to $\mathrm{F}$. auriculata (Basso-Alves et al., 2014; present study) and in F. ulmifolia comparatively to $\mathrm{F}$. asperifolia (present study) in which stylar trichomes are absent. Furthermore, stigmata are perfectly separated in "female" F. montana (unpublished observation). An entanglement of stigmata through papillae, forming loose or cohesive synstigmata is generally found in monoecious actively pollinated species, as reported here in F. lyrata, F. microcarpa, F. racemosa and F. religiosa. In F. religiosa and F. racemosa the tight cohesion between papillae is provided by the cell walls. In the region of contact between papillae, the middle lamella is discontinuous or even absent, indicating that there is true union of cell walls. 

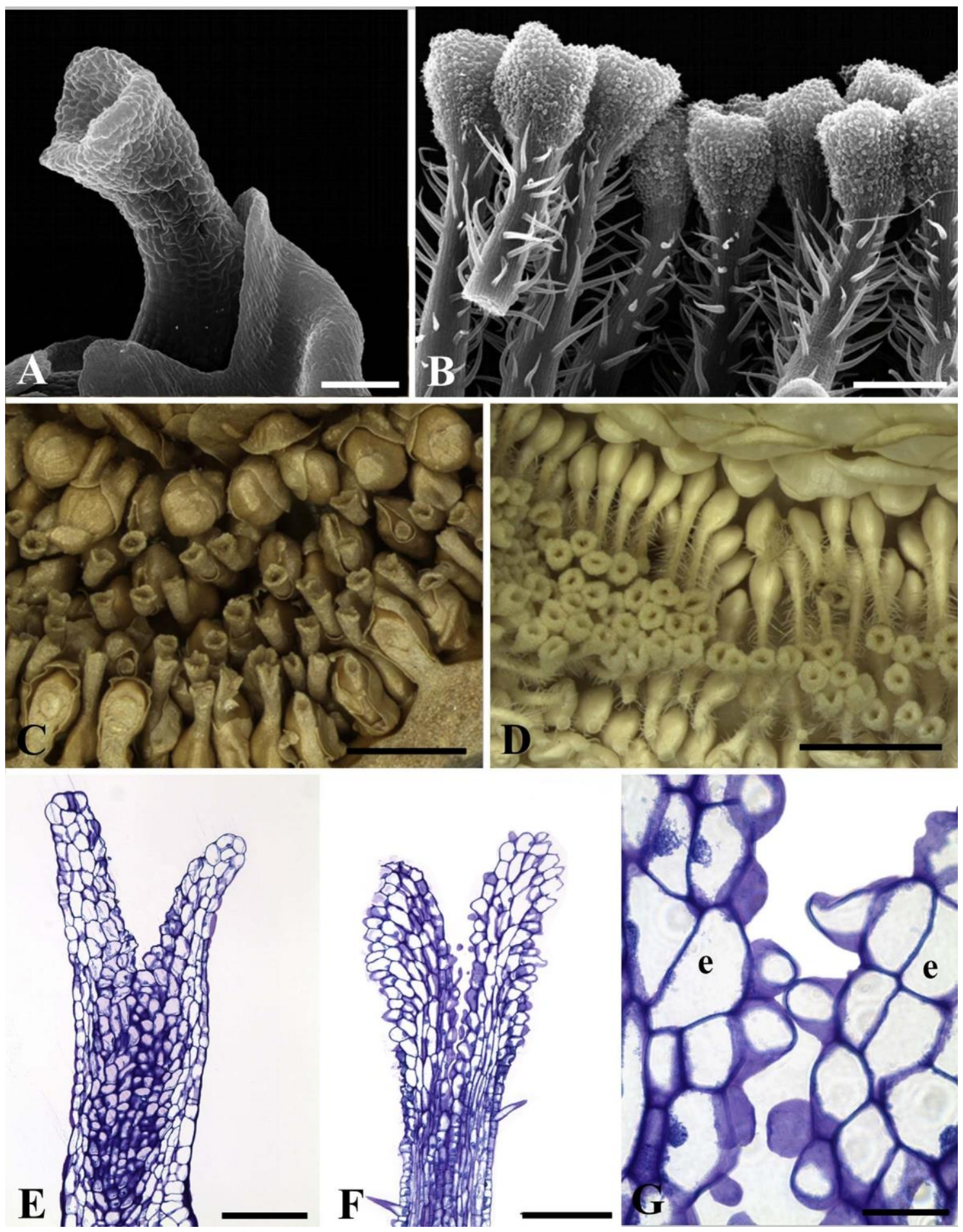

Fig. 8. Stigmata of short-styled (A, C, E) and long-styled (B, D, F, G) flowers of Ficus septica (gynodioecious, active). A. Infundibuliforme stigma (SEM). B. Infundibuliform stigma covered by papillae. Note the stylar trichomes (SEM). C. No synstigma is found in a "male syconium" 
(LM). D. Groups of synstigmata in a "female syconium" (LM). E. Stigmatic surface formed by convex cells (LM). F. Stigmatic surface formed by papillae (LM). G. Detail of papillae in a connection between two stigmata (LM). Symbol: e = stigma. Scale bars: A, E, F = $100 \mu \mathrm{m}$; $\mathrm{B}=200 \mu \mathrm{m} ; \mathrm{C}, \mathrm{D}=1 \mathrm{~mm} ; \mathrm{G}=20 \mu \mathrm{m}$.

In the other Rosales, an order to which Moraceae belongs (APG IV, 2016), a structure similar to a synstigma was reported in two Procris species (Urticaceae, Weberling, 1989) and in Rosa setigera (Rosaceae, Kemp et al., 1993). In Procris the congested inflorescence organization seems to promote the union of stigmata in inflorescences with pistillate flowers. In Rosaceae, species belonging to the section Synstylae are characterized by the presence of a column of united styles and a synstigma.

The Ficus gynoecium is functionally apocarpic, since a reduction occurs (i.e., pseudomonomery) that results in a uniovulate pistil per flower (Eckardt, 1937). In taxa that have
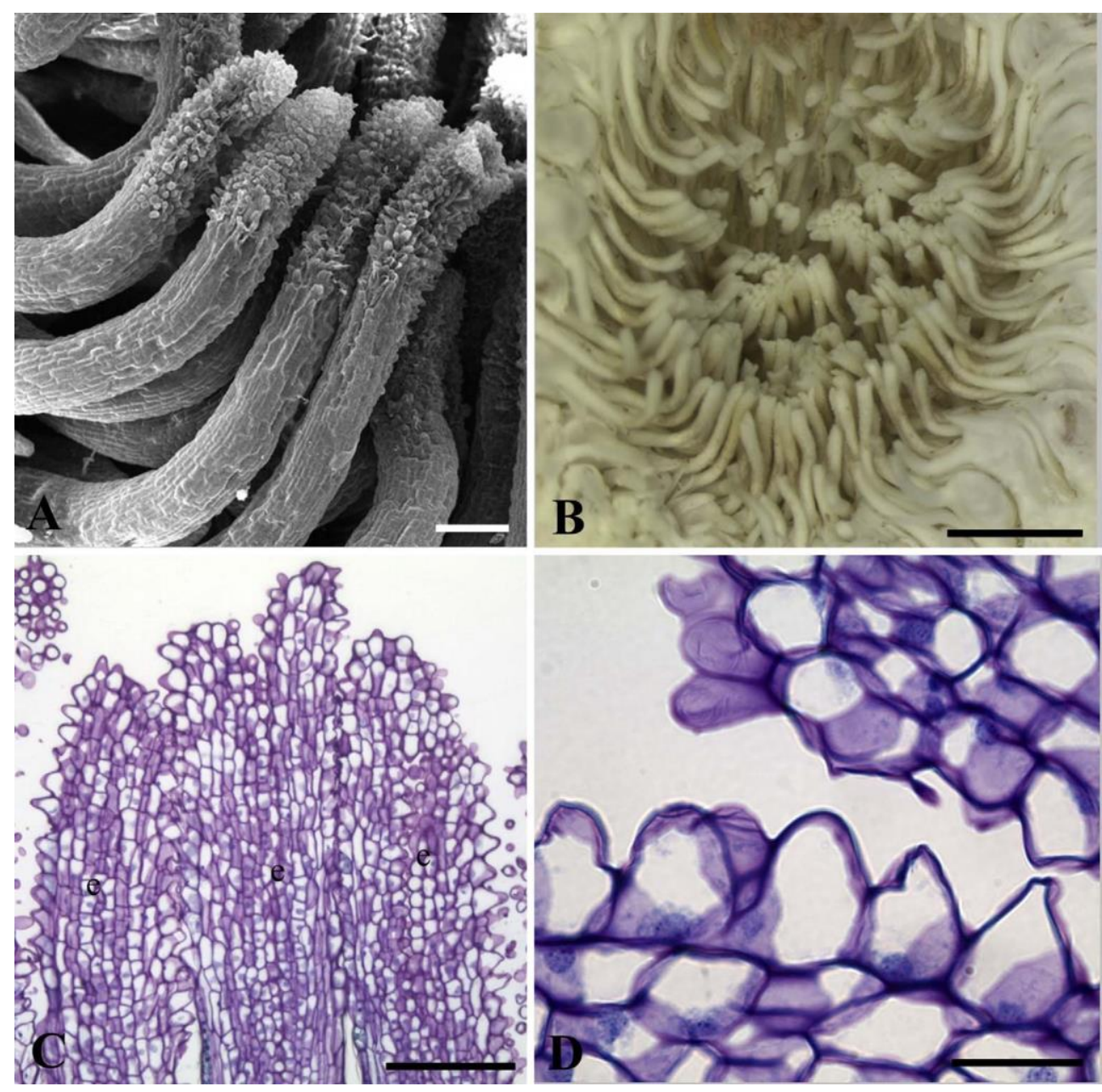

Fig. 9. Stigmata of a long-styled flower of Ficus ulmifolia (gynodioecious, active). A. Tubular stigmata (SEM). B. Synstigma formed by the entanglement of papillae (LM). C. Several 
stigmata connected by papillae (LM). D. Detail of papillae with a thin smooth cuticle (LM). Scale bars: $A, C=100 \mu \mathrm{m} ; \mathrm{B}=1 \mathrm{~mm} ; \mathrm{D}=20 \mu \mathrm{m}$.

a syncarpic gynoecium, the region of pollen tube assembly is called a compitum (Endress, 2011) and allows the equitable distribution of the pollen tubes between carpels (Endress and Igersheim, 2000) in addition to acting as a site of selection and competition of the pollen tubes (Endress, 1982). In this context, the synstigma of Ficus is functionally analogous to an extragynoecial compitum, as reported for some apocarpic plant groups, such as Austrobaileyaceae (Endress, 1982; Endress and Igersheim, 2000), Illiciaceae (Endress and Igersheim, 2000), Monimiaceae (Endress, 1979; Endress and Lorence, 1983), Nymphaeaceae (Endress and Igersheim, 2000), and Schisandraceae (Du and Wang, 2012; Endress, 1982; Lyew et al., 2007), in its distribution of pollen components. A common type of extra-gynoecial compitum, found among basal angiosperm lineages, involves abundant stigmatic mucilaginous exudate (Endress, 2011, 1979; Endress and Igersheim, 2000; Endress and Lorence, 1983; Wang et al., 2012), this mucillage constituting a medium for pollen germination, selection and distribution. An extreme case of this condition is described as "hyperstigma" in Monimiaceae (Endress, 1982, 1979). Indeed, some Monimiaceae species show many affinities with Ficus pollination biology. At least species of Mollinedia, Steganthera and Wilkiea seem to be involved in a breeding-site pollination mutualism with Thysanoptera insects and the gross appearance of their flowers resembles the inflorescence of Ficus (Endress, 1979). However, the Ficus stigma appears to be dry (Heslop-Harrison and Shivanna, 1977; Ramírez-Benavides, 2007), and their mutual cohesion is mechanical, similar to that provided by the post-genital union of the distal parts of carpels of Apocynaceae, Malvaceae and Sapindales (Endress et al., 1983; Vieira and Shepherd, 2002).

\section{Conclusions}

The main differences in stigma structure documented here in Ficus can be readily explained in adaptive and historical terms. However, within each type of reproductive system (active versus passive pollination, monoecious versus gynodioecious breeding system), variation in synstigma structure is observed, even within sections, suggesting that within a general system, the fine biology of the interaction between figs and wasps may vary. For instance, this study is the first to report a very loose synstigma in actively pollinated monoecious species. Further investigation could replicate species within Ficus groups, especially from subgenus Synoecia, sections Eriosycea and Oreossycea, and subsection Frutescentiae that were not included here. Also, comparative studies will be required to test further hypotheses about the evolutionary determinants of such variation. 
Author contribution

S.P. Teixeira and R.A.S. Pereira conceived and designed the experiments. M.F.B. Costa performed the experiments. All authors analyzed the data. S.P. Teixeira, J.P. Basso-Alves, F. Kjellberg and R.A.S. Pereira wrote the manuscript.

Acknowledgments

We thank Edimárcio S. Campos (Botany Laboratory, FCFRP/USP), José

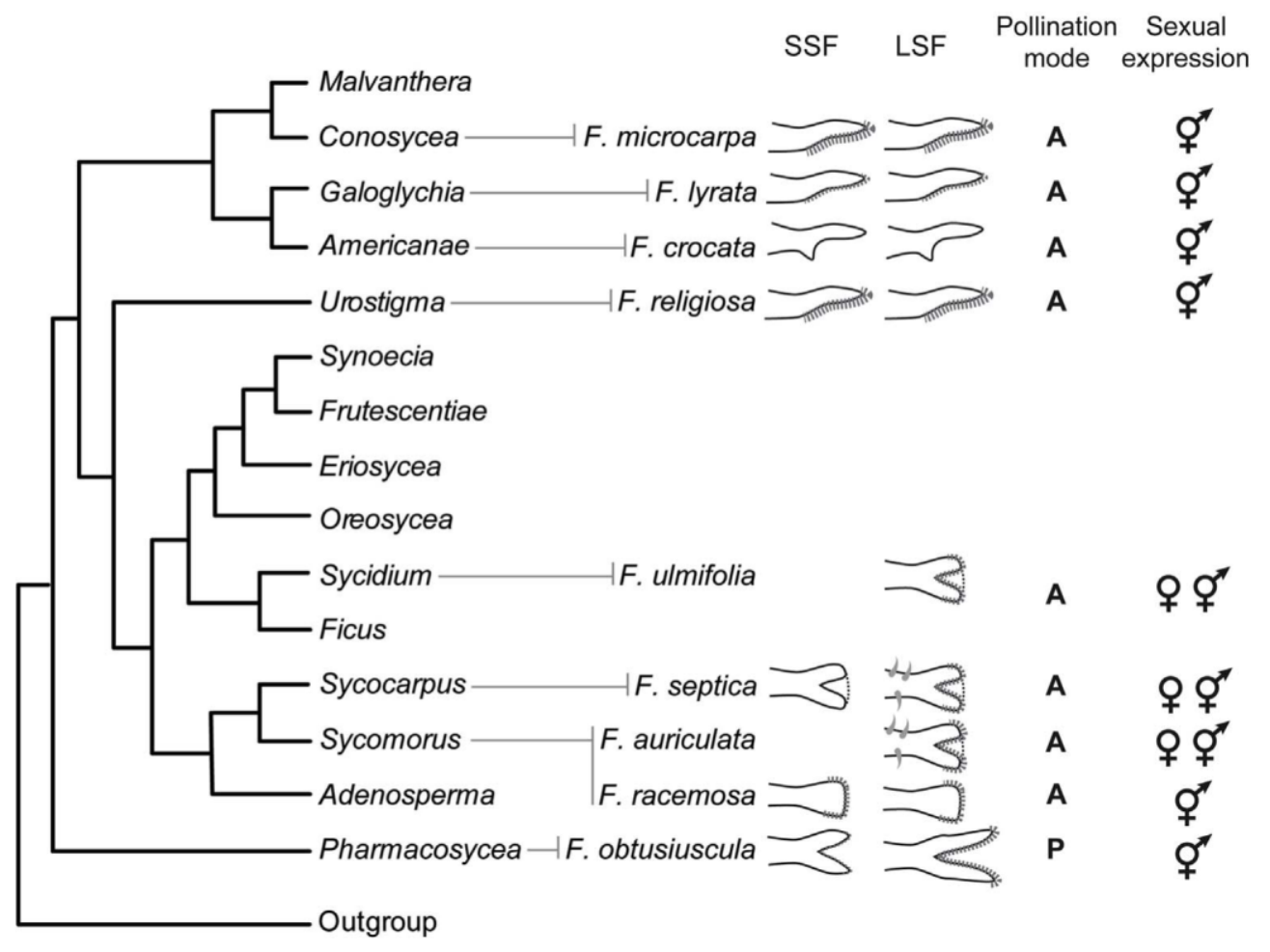

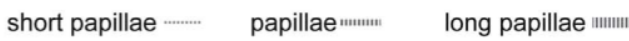

Fig. 10. Phylogenetic hypothesis showing the stigma diversity found in the species studied of Ficus (modified from Cruaud et al., 2012). The terminal branches show the stigma shape and cellular composition in shorter-styled flower (SSF) and longer-styled flower (LSF), the pollination mode $(\mathrm{A}=$ ative, $\mathrm{P}=$ passive $)$ and the sexual expression

Augusto Maulin, Maria Dolores Seabra Ferreira (LMME, FMRP/ USP) and Rodrigo F. Silva (Chemistry Department, FFCLRP/USP) for technical assistance, Priscila C. Costa, Fernando H. A. Farache (FFCLRP/USP) and Lillian J. V. Rodriguez (University of the Philippines Diliman) for some Ficus samples, and Elettra Greene for the English revision. This work was supported by FAPESP (grant numbers 2012/ 02374-2 and 2014/07453-3); CNPq (grant numbers 
306078/2014-7 and 303493/2015-1); and FAPERJ (grant numbers E-26/202.411/2017 and E26/202.412/2017).

\section{References}

APG, I.V., 2016. An update of the Angiosperm Phylogeny Group classification for the orders and families of flowering plants: APG IV. Bot. J. Linn. Soc. 181, 1-20. http:// dx.doi.org/10.1111/boj.12385.

Banks, H., Rudall, P.J., 2016. Pollen structure and function in caesalpinioid legumes. Am. J. Bot. 103, 423-436. http://dx.doi.org/10.3732/ajb.1500248.

Basso-Alves, J.P., Agostini, K., Teixeira, S.P., 2011. Pollen and stigma morphology of some Phaseoleae species (Leguminosae) with different pollinators. Plant Biol. (N. Y.) 13, 602610. http://dx.doi.org/10.1111/j.1438-8677.2010.00416.x.

Basso-Alves, J.P., Pereira, R.A.S., Peng, Y.-Q., Teixeira, S.P., 2014. Different ontogenetic processes promote dicliny in Ficus L. (Moraceae). Acta Oecol. 57, 5-16. http://dx.doi. org/10.1016/j.actao.2013.02.012.

Beck, N.G., Lord, E.M., 1988a. Breeding system in Ficus carica, the common fig. I. floral diversity. Am. J. Bot. 75, 1904-1912. http://dx.doi.org/10.2307/2444745.

Beck, N.G., Lord, E.M., 1988b. Breeding system in Ficus carica, the common fig. II. pollination events. Am. J. Bot. 75, 1913-1922. http://dx.doi.org/10.2307/2444746.

Berg, C.C., 1972. Olmedieae, Brosimeae (Moraceae). Flora Neotrop. 7, 1-228.

Berg, C.C., 1989. Systematics and phylogeny of the urticales. In: In: Crane, P.R., Blackmore, S. (Eds.), Evolution, Systematics, and Fossil History of the Hamamelidae, Vol. 2, Higher Hamamelidae Clarendon Press, Oxford, pp. 193-220.

Berg, C.C., 1990. Reproduction and evolution in Ficus (Moraceae): traits connected with the adequate rearing of pollinators. Mem. N. Y. Bot. Gard 55, 169-185.

Berg, C.C., 2005. Moraceae diversity in a global perspective. Biol. Skr. 55, 423-440.

Berg, C.C., 2006. The subdivision of Ficus subgenus Pharmacosycea section Pharmacosycea (Moraceae). Blumea 51, 147-151. http://dx.doi.org/10.3767/ 000651906X622409.

Berg, C.C., Avila, M.V., Kooy, F., 1984. Ficus species of Brazilian amazonia and the guianas. Acta Amazonica 14, 159-194. http://dx.doi.org/10.1590/180943921984145194.

Berg, C.C., Corner, E.J.H., 2005. Flora Malesiana. Series I, Seed Plants. Volume 17, Part 2: Moraceae (Ficus). Nationaal Herbarium Nederland, Leiden, Netherlands.

Berg, C.C., Villavicencio, X., 2004. Taxonomic studies on Ficus (Moraceae) in the west indies, extra-amazonian Brazil and Bolivia. Ilicifolia 5, 1-177.

Berg, C.C., Wiebes, J.T., 1992. African Figs and Fig wasps. Koninklijke Nederlandse Akademie Van Wetenschappen Verhandelingen Afdeling Natuurkunde. Amsterdam.

Bigazzi, M., Selvi, F., 2000. Stigma form and surface in the tribe Boragineae (Boraginaceae): micromorphological diversity, relationships with pollen, and systematic relevance. Can. J. Bot. 78, 388-408. http://dx.doi.org/10.1139/b00-014.

Brown, G.K., Gilmartin, A.J., 1989. Stigma types in Bromeliaceae - a systematic survey. Syst. Bot. 14, 110-132. http://dx.doi.org/10.2307/2419055. 
Carr, S.G.M., Carr, D.J., 1961. The functional significance of syncarpy. Phytomorphology 11, 249-256.

Corner, E.J.H., 1970. Ficus subg. Pharmacosycea with reference to the species of New Caledonia. Philos. Trans. R. Soc. London, Ser. A B 259, 383-433. http://dx.doi.org/ 10.1098/rstb.1970.0062.

Corner, E.J.H., 1978. Ficus dammaropsis and the multibracteate species of Ficus sect. Sycocarpus. Philos. Trans. R. Soc. Lond. B Biol. Sci. 281, 373-406. http://dx.doi.org/ 10.1098/rstb.1978.0003.

Cruaud, A., Jabbour-Zahab, R., Genson, G., Cruaud, C., Couloux, A., Kjellberg, F., van Noort, S., Rasplus, J.-Y., 2010. Laying the foundations for a new classification of Agaonidae (Hymenoptera: chalcidoidea), a multilocus phylogenetic approach.

Cladistics 26, 359-387. http://dx.doi.org/10.1111/j.1096-0031.2009.00291.x.

Cruaud, A., Rønsted, N., Chantarasuwan, B., Chou, L.S., Clement, W.L., Couloux, A., Cousins, B., Genson, G., Harrison, R.D., Hanson, P.E., Hossaert-McKey, M., JabbourZahab, R., Jousselin, E., Kerdelhue, C., Kjellberg, F., Lopez-Vaamonde, C., Peebles, J., Peng, Y.-Q., Pereira, R.A.S., Schramm, T., Ubaidillah, R., van Noort, S., Weiblen, G.D., Yang, D.-R., Yodpinyanee, A., Libeskind-Hadas, R., Cook, J.M., Rasplus, J.-Y., Savolainen, V., 2012. An extreme case of plant-insect codiversification: figs and figpollinating wasps. Syst. Biol. 61, 1029-1047. http://dx.doi.org/10.1093/sysbio/ sys068.

Datwyler, S.L., Weiblen, G.D., 2004. On the origin of the fig: phylogenetic relationships of Moraceae from ndhF sequences. Am. J. Bot. 91, 767-777. http://dx.doi.org/10.3732/ ajb.91.5.767.

Du, W., Wang, X.-F., 2012. Intercarpellary growth of pollen tubes in the extragynoecial compitum and its contribution to fruit set in an apocarpous species, Schisandra sphenanthera (Schisandraceae). Am. J. Bot. 99, 961-966. http://dx.doi.org/10.3732/ ajb.1100165.

Eckardt, T., 1937. Untersuchungen über Morphologie, Entwicklungsgeschichte und systematische Bedeutung des pseudomonomeren Gynoeceums. Nov. Acta Leopoldina 5, 1112.

Edlund, A.F., Swanson, R., Preuss, D., 2004. Pollen and stigma structure and function: the role of diversity in pollination. Plant Cell 16 (Suppl. 1), S84-S97. http://dx.doi.org/ 10.1105/tpc.015800.

Endress, P.K., 1979. Noncarpellary pollination and "hyperstigma" in an angiosperm (Tambourissa religiosa, Monimiaceae). Experientia 35http://dx.doi.org/10.1007/ BF01917867. 45-45.

Endress, P.K., 1982. Syncarpy and alternative modes of escaping disadvantages of apocarpy in primitive angiosperms. Taxon 31, 48-52. http://dx.doi.org/10.2307/ 1220588.

Endress, P.K., 1994. Diversity and Evolutionary Biology of Tropical Flowers, Cambridge Tropical Biology Series. Cambridge University Press, Cambridge.

Endress, P.K., 2011. Evolutionary diversification of the flowers in angiosperms. Am. J. Bot. 98, 370-396. http://dx.doi.org/10.3732/ajb.1000299. 
Endress, P.K., Igersheim, A., 2000. Gynoecium structure and evolution in basal angiosperms. Int. J. Plant Sci. 161, S211-S213. http://dx.doi.org/10.1086/317572.

Endress, P.K., Jenny, M., Fallen, M.E., 1983. Convergent elaboration of apocarpous gynoecia in higher advanced dicotyledons (Sapindales, Malvales, Gentianales). Nord. J.

Bot. 3, 293-300. http://dx.doi.org/10.1111/j.1756-1051.1983.tb01941.x.

Endress, P.K., Lorence, D.H., 1983. Diversity and evolutionary trends in the floral structure of Tambourissa (Monimiaceae). Plant Systemat. Evol. 143, 53-81. http://dx. doi.org/10.1007/BF00984112.

Erbar, C., 2003. Pollen tube transmitting tissue: place of competition of male gametophytes. Int. J. Plant Sci. 164, S265-S277. http://dx.doi.org/10.1086/377061.

Galil, J., Eisikowitch, D., 1968. On the pollination ecology of Ficus sycomorus in East Africa. Ecology 49, 259-269. http://dx.doi.org/10.2307/1934454.

Galil, J., Eisikowitch, D., 1969. Note on pollen transport, pollination and protection of ovaries in Ficus sycomorus. New Phytol. 68, 1243-1244. http://dx.doi.org/10.1111/j. 14698137.1969.tb06520.x.

Galil, J., Snitzer-Pasternak, Y., 1970. Pollination in Ficus religiosa L. as connected with the structure and mode of action of pollen pockets of Blastophaga quadraticeps Mayr. New Phytol. 69, 775-784. http://dx.doi.org/10.1111/j.1469-8137.1970.tb02462.x.

Gerrits, P.O., Horobin, R.W., 1991. The Application of Glycol Methacrylate in Histotechnology; Some Fundamental Principles. Faculteit der Geneeskunde, Rijksuniversiteit Groningen.

Heslop-Harrison, J., 1982. Pollen-stigma interaction and cross-incompatibility in the grasses. Science 215, 1358-1364. http://dx.doi.org/10.1126/science.215.4538. 1358.

Heslop-Harrison, J., Heslop-Harrison, Y., Barber, J.C., 1975. The stigma surface in incompatibility responses. Proc. R. Soc. B Biol. Sci. 188, 287-297. http://dx.doi.org/ 10.1098/rspb.1975.0020.

Heslop-Harrison, J., Heslop-Harrison, Y., 1985. Surfaces and secretions in the pollenstigma interaction: a brief review. J. Cell Sci. 1985, S287-S300. http://dx.doi.org/10. 1242/jcs.1985.Supplement_2.15.

Heslop-Harrison, J.S., 1992. The angiosperm stigma. In: Cresti, M., Tiezzi, A. (Eds.), Sexual Plant Reproduction. Springer Berlin Heidelberg, Berlin, Heidelberg, pp. 59-68. http://dx.doi.org/10.1007/978-3-642-77677-9_6.

Heslop-Harrison, Y., 1981. Stigma characteristics and angiosperm taxonomy. Nord. J. Bot. 1, 401-420. http://dx.doi.org/10.1111/j.1756-1051.1981.tb00707.x.

Heslop-Harrison, Y., 2000. Control gates and micro-ecology: the pollen-stigma interaction in perspective. Ann. Bot 85, 5-13. http://dx.doi.org/10.1006/anbo.1999.1063.

Heslop-Harrison, Y., Shivanna, K.R., 1977. The receptive surface of the angiosperm stigma. Ann. Bot 41, 1233-1258. http://dx.doi.org/10.2307/42765288.

Hesse, M., 2000. Pollen wall stratification and pollination. Plant Systemat. Evol. 222, 1-17. http://dx.doi.org/10.1007/BF00984093. 
Jansen-González, S., Teixeira, S.P., Pereira, R.A.S., 2012. Mutualism from the inside: coordinated development of plant and insect in an active pollinating fig wasp.

Arthropod. Plant. Inte 6, 601-609. http://dx.doi.org/10.1007/s11829-012-9203-6. Johansen,

D.A., 1940. Plant Microtechnique. McGraw-Hill, New York.

Jousselin, E., Kjellberg, F., 2001. The functional implications of active and passive pollination in dioecious figs. Ecol. Lett. 4, 151-158. http://dx.doi.org/10.1046/j.14610248.2001.00209.x.

Jousselin, E., Hossaert-McKey, M., Herre, E.A., Kjellberg, F., 2003a. Why do fig wasps actively pollinate monoecious figs? Oecologia 134, 381-387. http://dx.doi.org/10. 1007/s00442-002-1116-0.

Jousselin, E., Rasplus, J.-Y., Kjellberg, F., 2003b. Convergence and coevolution in a mutualism: evidence from a molecular phylogeny of Ficus. Evolution 57, 1255-1269.

Jousselin, E., Kjellberg, F., Herre, E.A., 2004. Flower specialization in a passively pollinated monoecious fig: a question of style and stigma? Int. J. Plant Sci. 165, 587-593. http://dx.doi.org/10.1086/386558.

Katinas, L., Hernández, M.P., Arambarri, A.M., Funk, V.A., 2016. The origin of the bifurcating style in Asteraceae (Compositae). Ann. Bot 117, 1009-1021. http://dx.doi. org/10.1093/aob/mcw033.

Kemp, J.R., Posluszny, U., Gerrath, J.M., Kevan, P.G., 1993. Floral development of Rosa setigera. Can. J. Bot. 71, 74-86. http://dx.doi.org/10.1139/b93-009.

Kjellberg, F., Jousselin, E., Bronstein, J.L., Patel, A., Yokoyama, J., Rasplus, J.-Y., 2001. Pollination mode in fig wasps: the predictive power of correlated traits. Proc. Biol. Sci. 268, 1113-1121. http://dx.doi.org/10.1098/rspb.2001.1633.

Kjellberg, F., Jousselin, E., Hossaert-McKey, M., Rasplus, J.-Y., 2005. Biology, ecology and evolution of fig pollinating wasps (Chalcidoidea: agaonidae). In: Raman, A., Schaefer, C.W., Withers, T.M. (Eds.), Biology, Ecology and Evolution of Gall Inducing Arthropods. Science Publishers Inc., Plymouth, UK, pp. 539-572.

Kjellberg, F., Suleman, N., Raja, S., Tayou, A., Hossaert-McKey, M., Compton, S.G., 2014. Some pollinators are more equal than others: factors influencing pollen loads and seed set capacity of two actively and passively pollinating fig wasps. Acta Oecol. 57, 73-79. http://dx.doi.org/10.1016/j.actao.2013.11.002.

Leclerc du Sablon, M., 1908. Observations sur les diverses formes du figuier. Rev. Gen. Bot. 20, 129-150 207-216.

Lillie, R.D., 1954. Histopathologic Technic and Practical Histochemistry. McGraw-Hill Book Co, New York.

Lora, J., Herrero, M., Hormaza, J.I., 2011. Stigmatic receptivity in a dichogamous earlydivergent angiosperm species, Annona cherimola (Annonaceae): influence of temperature and humidity. Am. J. Bot. 98, 265-274. http://dx.doi.org/10.3732/ajb. 1000185. 
Lora, J., Hormaza, J.I., Herrero, M., 2016. The diversity of the pollen tube pathway in plants: toward an increasing control by the sporophyte. Front. Plant Sci. 7, 107. http://dx.doi.org/10.3389/fpls.2016.00107.

Lyew, J., Li, Z., Liang-Chen, Y., Luo, Y.B., Sage, T.L., 2007. Pollen tube growth in association with a dry-type stigmatic transmitting tissue and extragynoecial compitum in the basal angiosperm Kadsura longipedunculata (Schisandraceae). Am. J. Bot. 94, 1170-1182. http://dx.doi.org/10.3732/ajb.94.7.1170.

McDowell, E.M., Trump, B.F., 1976. Histologic fixatives suitable for diagnostic light and electron microscopy. Arch. Pathol. Lab Med. 100, 405-414.

O'Brien, T.P., Feder, N., McCully, M.E., 1964. Polychromatic staining of plant cell walls by toluidine blue O. Protoplasma 59, 368-373. http://dx.doi.org/10.1007/ BF01248568.

Osborn, J.M., Taylor, T.N., Schneider, E.L., 1991. Pollen morphology and ultrastructure of the Cabombaceae: correlations with pollination biology. Am. J. Bot. 78, 1367-1378. http://dx.doi.org/10.2307/2445275.

Payer, J.-B., 1857. Traité d'organogénie comparée de la fleur. （Masson, Paris).

Pearse, A.G.E., 1980. Histochemistry, Theoretical and Applied: Preparative and Optical Technology, fourth ed. Churchill Livingston, Edinburgh, UK.

Ramírez -Benavides, W., 1969. Fig wasps: mechanism of pollen transfer. Science 163, 580581. http://dx.doi.org/10.1126/science.163.3867.580.

Ramírez-Benavides, W., 2007. Pollination analogies between orchidaceae, Ficus (Moraceae) and asclepiadaceae. Lankesteriana 7, 450-457. http://dx.doi.org/10. 15517/lank.v7i1-2.19668.

Rejón, J.D., Delalande, F., Schaeffer-Reiss, C., Carapito, C., Zienkiewicz, K., Alché, J., de, D., Rodríguez-García, M.I., Van Dorsselaer, A., Castro, A.J., 2014. The plant stigma exudate. Plant Signal. Behav. 9, e28274. http://dx.doi.org/10.4161/psb.28274.

Reynolds, E.S., 1963. The use of lead citrate at high $\mathrm{pH}$ as an electron-opaque stain in electron microscopy. J. Cell Biol. 17, 208-212. http://dx.doi.org/10.1083/jcb.17.1. 208.

Rønsted, N., Weiblen, G.D., Savolainen, V., Cook, J.M., 2008. Phylogeny, biogeography, and ecology of Ficus section Malvanthera (Moraceae). Mol. Phylogenet. Evol. 48, 12-22. http://dx.doi.org/10.1016/j.ympev.2008.04.005.

Sakai, S., 2001. Thrips pollination of androdioecious Castilla elastica (Moraceae) in a seasonal tropical forest. Am. J. Bot. 88, 1527-1534. http://dx.doi.org/10.2307/ 3558396.

Sigrist, M.R., Sazima, M., 2004. Pollination and reproductive biology of twelve species of neotropical Malpighiaceae: stigma morphology and its implications for the breeding system. Ann. Bot 94, 33-41. http://dx.doi.org/10.1093/aob/mch108.

The Plant List 2013. Version 1.1. Published on the Internet; http://www.theplantlist.org/ (accessed 16 February 2017).

van Went, J.L., Willemse, M.T.M., 1984. Fertilization. In: Johri, B.M. (Ed.), Embryology of Angiosperms. Springer Berlin Heidelberg, Berlin, Heidelberg, pp. 273-317. http://dx. doi.org/10.1007/978-3-642-69302-1_6. 
Verkerke, W., 1986. Anatomy of Ficus ottoniifolia (Moraceae) syconia and its role in the figfig wasp symbiosis. Proc. K. Ned. Akad. Wet. C. 89, 443-469.

Verkerke, W., 1987. Syconial anatomy of Ficus asperifolia (Moraceae), a gynodioecious tropical fig. Proc. K. Ned. Akad. Wet. C. 90, 461-492.

Verkerke, W., 1989. Structure and function of the fig. Experientia 45, 612-622. http://dx. doi.org/10.1007/BF01975678.

Vieira, M.F., Shepherd, G.J., 2002. Oxypetalum banksii subsp. banksii: a taxon of Asclepiadaceae with an extragynoecial compitum. Plant Systemat. Evol. 233, 199-206. http://dx.doi.org/10.1007/s00606-002-0204-2.

Wang, G., Chen, J., Li, Z.-B., Zhang, F.-P., Yang, D.-R., 2014. Has pollination mode shaped the evolution of Ficus pollen? PLoS One 9 (1), e86231. http://dx.doi.org/10.1371/ journal.pone.0086231.

Wang, X.-F., Armbruster, W.S., Huang, S.Q., 2012. Extra-gynoecial pollen-tube growth in apocarpous angiosperms is phylogenetically widespread and probably adaptive. New Phytol. 193, 253-260. http://dx.doi.org/10.1111/j.1469-8137.2011.03912.x.

Weberling, F., 1989. Morphology of Flowers and Inflorescences. Cambridge University Press, Cambridge.

Weiblen, G.D., 2000. Phylogenetic relationships of functionally dioecious Ficus (Moraceae) based on ribosomal DNA sequences and morphology. Am. J. Bot. 87, 1342-1357. http://dx.doi.org/10.2307/2656726.

Zhang, F.P., Peng, Y.-Q., Compton, S.G., Yang, D.-R., 2009. Floral characteristics of Ficus curtipes and the oviposition behavior of its pollinator fig wasp. Ann. Entomol. Soc.

Am. 102, 556-559. http://dx.doi.org/10.1603/008.102.0328. 